\title{
Invited review: Sugar reduction in dairy products
}

\author{
H. R. McCain, ${ }^{*}$ S. Kaliappan, $†$ and M. A. Drake*1 \\ *Department of Food, Bioprocessing and Nutrition Sciences, Southeast Dairy Foods Research Center, Box 7624, North Carolina State University, \\ Raleigh 27695-7624 \\ †National Dairy Council, 10255 W. Higgins Rd., Rosemont, IL 60018
}

\section{ABSTRACT}

Sugar overconsumption continues to increase worldwide and contributes to multiple health-related issues. Dairy foods represent a large market, grossing more than $\$ 125$ billion per year worldwide. Consumer demands for healthier products are leading to a large push for sugar reduction in dairy foods. Sugar plays an important role in dairy foods, not only in flavor but also in texture, color, and viscosity. Replacing sugar can have negative effects, making substitution inherently difficult. Natural and artificial nonnutritive sweeteners exist for sugar reduction. Natural nonnutritive sweeteners are popular, particularly for label appeal, but many consumers still prefer the taste of artificial nonnutritive sweeteners. Sweet taste perception can also be affected by texture of the food matrix and the presence of fat. Other sugar reduction techniques include hydrolysis of lactose, ultrafiltration, and direct reduction. This review will address the role of sugar, alternative sweeteners, and sugar reduction in ice cream, yogurt, and flavored milk. Key words: sugar reduction, dairy food, sweetener

\section{INTRODUCTION}

Humans are born with an innate preference for sweet taste (Behrens et al., 2011). Infant studies have shown that the sweeter a beverage is the more babies will consume of it (Ganchrow et al., 1983; Yebra-Biurrun, 2005). Sugar increases the perceived pleasure of eating and if removing sugar causes a negative impact on product sales through lower consumption, companies will not be motivated to invest in decreasing sugar content unless positive solutions are developed (Yebra-Biurrun, 2005). Furthermore, consumers who tend to consume more sugar-sweetened beverages have a higher affinity for sweet taste, which further encourages companies to add more sugar into products until it reaches the consumer "bliss point" (Mahar and Duizer, 2007; Moss,

\footnotetext{
Received December 25, 2017.

Accepted May 21, 2018.

${ }^{1}$ Corresponding author: mdrake@ncsu.edu
}

2013). Moss (2013) defines the bliss point as the precise amount of sugar that will send consumers "over the moon" for the product, addicting them to the product and causing them to overeat. However, overconsumption of sugar can contribute to a host of issues such as hypertension, type 2 diabetes, cardiovascular disease, and dental cavities (WHO, 2003; Grembecka, 2015). Daily sugar consumption is close to $500 \mathrm{kcal}$ per day worldwide, whereas the recommended daily intake of sugar for a normal weight individual is about $25 \mathrm{~g}$ or 96 kcal per day (Lustig et al., 2012; Mann et al., 2013; WHO, 2017). The Centers for Disease Control and Prevention report that an estimated $36 \%$ of adults over the age of 20 and $17 \%$ of children and adolescents from 2 to $19 \mathrm{yr}$ are obese (Jeong et al., 2014). The World Health Organization (WHO, 2003) suggested that sugar should make up only $10 \%$ or less of total dietary energy consumption, but on average, sugar contributes much more. In the United States, a simple reduction in the consumption of added sugar is projected to potentially prevent 2.4 million cases of diabetes, 8,000 strokes, and 26,000 premature deaths per year (Wang et al., 2012; Mekonnen et al., 2013). Although sugar is not the sole cause of the obesity epidemic, it is a major contributor (Pruthi, 2015).

The prevalence and increase of numerous diseases has continued to spark consumer interest in reducing sugar in dairy and other food products. Sugar-sweetened beverages, such as flavored milk, soda, sport drinks, and sweetened tea, are the highest contributors to added sugar in American diets; in 2009, 13.8 billion gallons of sugar-sweetened beverages were consumed (Wang et al., 2012). "Added sugar" refers to sugar added to food before consumption, during preparation, or during processing to enhance flavor or texture of foods, as opposed to the sugar inherently present in a food (Anton et al., 2010; Yoo et al., 2017). Added sugar and sugar naturally present in food do not differ chemically, but there is a large health concern about added sugar due to the addition of unnecessary calories (Edwards et al., 2016).

Over the past 2 decades, consumer focus on health has increased, leading to a significant push for healthier 
food choices (Thompson and Moughan, 2008; Chen, 2011; Küster and Vila, 2017). In general, consumers have a basic understanding of nutrition in regards to sugar but what differentiates a healthy consumer from an unhealthy consumer is how they use their nutritional knowledge to make food choices (Yeon and Lee, 2016). Many parents desire reduced-sugar products for their children, and current studies emphasize the importance of developing healthy eating habits at a young age (Chan et al., 2011; Byrd-Bredbenner et al., 2016). Sigman-Grant and Hsieh (2005) found that consumers who selected reduced-sugar versions or a combination of reduced-sugar and full-sugar products in general had more favorable diets. All socioeconomic levels of consumers can achieve healthier dietary practices by simply switching from a full-sugar food product to similarly priced reduced-sugar product. Food and dairy companies should offer consumers healthy alternatives that could help reduce sugar consumption (Küster and Vila, 2017). This review will investigate sugar alternatives and sugar reduction techniques in dairy foods.

\section{WHY IS THE DAIRY INDUSTRY INTERESTED IN SUGAR REDUCTION?}

\section{Health Benefits}

Dairy foods are popular in consumer food choices and sales gross more than $\$ 125$ billion per year (IDFA, 2017). With dairy product popularity comes new demands from consumers for healthier, low-calorie products that taste the same as their higher calorie counterparts. Dairy products such as yogurt, chocolate milk, custards, shakes, and ice cream are potentially high in unwanted added sugar. Some of the standard processes for developing healthier food products, such as fat, sugar, and salt reduction, produce unacceptable flavor in dairy products (Biguzzi et al., 2014). The dilemma of how to reduce sugar content without sacrificing flavor and negatively affecting product sales is challenging. Various methods exist for reducing sugar to improve the healthiness of dairy products without losing flavor, include direct reduction, sugar substitution, ultrafiltration, lactose hydrolysis, and many others, which will be addressed in this review.

\section{Regulatory Perspective}

To protect consumers from falsely advertised foods, sugar and sugar-free terms are regulated by the US Food and Drug Administration (FDA) in 21CFR101 (https://www.accessdata.fda.gov/scripts/cdrh/cfdocs/ cfcfr/CFRSearch.cfm?CFRPart=101). When a food is labeled "sugar-free," the claim indicates that the food contains no sugars or sweeteners and the food should be low in calories or significantly reduced in calories. The term "no sugar added" is reserved for foods that have no amount of sugar added and do not contain any ingredient with sugar added, such as jam or fruit juice concentrate. In the Nutrition Facts and Supplement Facts label new rule, added sugar will be declared separately from sugar naturally present in the food item (FDA, 2016a). For example, if the food has 12 $\mathrm{g}$ of sugar but $10 \mathrm{~g}$ comes from added sugar, that will be declared under the new label regulations. The compliance date for this new rule is currently July 2018 for companies with $\$ 10$ million or more in sales, and July 2019 for companies making less than $\$ 10$ million. Recently, the FDA proposed a rule to extend the Nutrition Facts and Supplement Facts label final deadline to January 2020 for large companies and January 2021 for smaller companies, but the proposal is still pending at this time (FDA, 2016a). Goldfein and Slavin (2015) point out that this new labeling regulation will create additional cost for ingredient and food manufacturers that will eventually be passed onto consumers. Additionally, Goldfein and Slavin (2015) pointed out that the new labeling will make added sugar "the enemy" to consumers, when it is not the sole cause of obesity.

"Reduced sugar" can be used to describe foods that contain at least $25 \%$ less sugar than the reference amount. In general, consumers prefer the "no sugar added" claim to the "reduced sugar" claim, most likely because they assume that other ingredients are added in place of sugar in the latter (Patterson et al., 2012). "Reference amount" refers to the specific amount of that food customarily consumed per eating occasion (21CFR101.12; https://www.accessdata.fda.gov/ scripts/cdrh/cfdocs/cfcfr/cfrsearch.cfm?fr $=101.12)$. For example, when a chocolate milk is labeled "reduced sugar," consumers can know that the milk contains at least $25 \%$ less sugar than the original product at the same reference amount ( $240 \mathrm{~mL}$ or $8 \mathrm{fl}$. oz.).

\section{SWEETENERS}

\section{Role of Sweeteners}

Sugar has many roles in foods; it not only makes foods more palatable but is also a bulking agent, adds viscosity, enhances flavor, provides texture, adds color, is a preservative, and inhibits protein coagulation (Davis, 1995; Silcock, 2017). Sugar acts as a bulking agent for many foods. When sugar is replaced or reduced, another bulking agent, such as insoluble fiber or polydextrose system, often must take its place (Silcock, 
Table 1. Terminology used to describe sweeteners in dairy foods

\begin{tabular}{ll}
\hline Term & Definition \\
\hline Nutritive & Provides energy in the form of carbohydrates while additionally contributing calories (FDA, 2015a) \\
Nonnutritive & $\begin{array}{l}\text { Very low in calories }(0.08 \mathrm{cal} / \mathrm{g} \text { ) or contain no calories at all; often sweeter than sugar on a weight by weight basis } \\
\text { (Antenucci and Hayes, 2014; USDA, 2015) }\end{array}$ \\
High-intensity ${ }^{1}$ & $\begin{array}{l}\text { Many times sweeter than sugar on a weight by weight basis but contribute only a few to no calories when added to } \\
\text { food (Shankar et al., 2013); for example, aspartame contains } 2 \% \text { of the calories of an equivalent amount of sugar } \\
\text { (aspartame 0.08 cal/g; sugar } 4 \text { cal/g) }\end{array}$ \\
Natural & $\begin{array}{l}\text { Refers to sweeteners already present in a food substance or occurring commonly in nature (Anton et al., 2010); for } \\
\text { example, sucrose, fructose, stevia, monk fruit, lactose }\end{array}$ \\
Artificial/synthetic & Synthetic sugar substitutes such as sucralose or aspartame that are noncaloric sweeteners (Sirshendu et al., 2013) \\
Noncaloric & Contribute no calories (Prakash et al., 2008; Sehar et al., 2008) \\
\hline
\end{tabular}

${ }^{1}$ All approved nonnutritive sweeteners are considered high-intensity sweeteners (Shankar et al., 2013).

2017). However, when sucrose is replaced with a bulking agent, the bulking agents also contribute calories to the product and may negate the original purpose of removing the sugar (Cardoso and Bolini, 2008). For example, maltodextrin is a common sugar replacer and bulking agent and it contributes the same amount of calories as sugar $(4 \mathrm{kcal} / \mathrm{g})$. Sugar can also add viscosity to foods and so, when it is removed, viscosity is reduced (Muir et al., 1998; Nurgel and Pickering, 2005; Kappes et al., 2006; Saint-Eve et al., 2009, 2010; Cadena et al., 2012; Leksrisompong et al., 2012). Sugar reduces the water activity of foods and beverages, which makes water unavailable for bacterial and fungal growth. Thus, when sugar is removed, it has to be replaced with another preservative, which is often less appealing to consumers. Sugar acts as an anticoagulant agent, in that it delays a liquid from changing into a solid or semi-solid state (Mizukoshi et al., 1979). For example, sugar delays the coagulation of proteins in many desserts, such as custards.

Another critical role that sugar plays is in color, through Maillard browning and caramelization. Maillard browning is a chemical reaction that occurs between an amino acid and a reducing sugar that requires the addition of heat (Damodaran et al., 2008; Varzakas, 2012). Maillard browning is responsible for the color and flavors in caramel, the browning of bread, and the color of maple syrup, condensed milk, cookies, and many other foods (Harrison and Dake, 2005). Caramelization (browning) occurs when carbohydrates are heated without nitrogen-containing compounds (protein) and it creates sweet and nutty flavors and brown color (Harrison and Dake, 2005; Damodaran et al., 2008). Both caramelization and Maillard browning are types of nonenzymatic browning that play critical roles in flavor and appearance of many foods.

\section{Terminology}

Terminology of sweeteners include natural, nutritive, high-intensity, artificial, and nonnutritive. These terms are currently not regulated by the FDA but definitions based on the literature are given in Table 1 (Antenucci and Hayes, 2014).

\section{Differences Between Natural and Artificial Sweeteners}

Sweeteners can be divided into 2 categories: natural and artificial (Servant et al., 2010; Lustig et al., 2012; Shankar et al., 2013). Currently there are many FDA-approved natural nutritive sweeteners, 2 natural nonnutritive sweeteners, and 7 FDA-approved artificial sweeteners, with more being developed (FDA, 2015a). Natural nutritive sweeteners provide energy (calories) to the body in the form of carbohydrates (FDA, 2015a). Examples include fructose (found in honey and agave), lactose (found in milk), and sucrose (table sugar). Sugar alcohols are another type of natural nutritive sweetener that have similar sweetness intensity to sucrose but contribute fewer calories due to slower and incomplete absorption in the intestine (Yebra-Biurrun, 2005; Grembecka, 2015). Sugar alcohols are additionally differentiated by a lower blood glucose response because they can be metabolized without insulin (Yebra-Biurrun, 2005; Grembecka, 2015). An example of a sugar alcohol that can be metabolized without insulin is lactitol or isomalt. Stevia and monk fruit are natural nonnutritive sweeteners found in the plants Stevia rebaudiana and Lo Han Guo (monk fruit), respectively, and they can be extracted from the plants, dried, and used as sweeteners. The first natural nonnutritive sweetener was approved for use by the FDA in 2009 (purified 
steviol glycosides with rebaudioside A as the principal component).

Artificial sweeteners are not found in nature and are synthesized. The first artificial sweetener (saccharin) was approved by the FDA in 1958, and the most recent artificial sweetener approved by the FDA was Advantame (Ajinomoto, Itasca, IL) in 2014. Artificial sweeteners can be synthesized from a natural source. For instance, sucralose is derived from sucrose but because it is derived or synthesized from sucrose, the sweetener is no longer considered "natural." Many consumers consider artificial sweeteners "unhealthy" perhaps due to studies dating back to the 1970s linking artificial sweetener (saccharin) to cancer in animals (Kroger et al., 2006; Larsen, 2012; Bearth et al., 2014; Chattopadhyay et al., 2014). These studies have been disproven and are no longer relevant but nonetheless contribute to the negative image of artificial sweeteners. More recently, a 2005 study in Italy linked aspartame with various types of cancer in rats (Kroger et al., 2006). Again, the study was disproven but nonetheless continues to cast artificial sweeteners in a negative light enough such that Diet Pepsi claims to be "aspartame free" (Kroger et al., 2006). Wardy et al. (2017) found that even the color of the sweetener packet (yellow, green, pink, blue, and white) elicited an emotional and hedonic response from consumers, caused by negative connotations of artificial sweeteners in specific color packets.

Consumers today desire an "all-natural" label and are willing to pay a premium for these foods as they are perceived as healthier (Rozin and Rozin, 2005; Anstine, 2007; Parasidis et al., 2015). Walters and Long (2012) found consumers with little nutrition knowledge were positively influenced by the "all-natural" label regardless of what the nutrition facts panel displayed. Ironically, McLean et al. (2017) determined that consumers preferred an "all-natural" label on bacon packages, even though this claim is not legally possible for bacon due to the addition of nitrates. Both Li et al. (2015a) and Oltman et al. (2015) determined that consumers preferred "naturally sweetened" labels on chocolate milk and protein beverages. Jervis et al. (2012a,b) also reported that "all natural" and "organic" claims were considered equally important to consumers and "all natural" was considered a very important term for consumers in sour cream and latte-style coffee beverages.

Natural and artificial sweeteners differ greatly in their sweetness potency. Natural sweeteners range from 0.1 to 450 times sweeter than sucrose (lactose and monk fruit, respectively), whereas artificial nutritive and nonnutritive sweeteners can be up to 20,000 times as sweet as sucrose (Advantame; Nofre and Tinti, 2000). When addressing sugar and calorie reduction, artificial sweeteners have more desirable taste profiles and when only flavor is considered (blind tasting), foods and beverages sweetened with artificial sweeteners generally score better than natural nonnutritive sweeteners (Morais et al., 2014; Voorpostel et al., 2014; Zorn et al., 2014; Kubica et al., 2015; Rocha and Bolini, 2015). Consumers have shown interest in natural sweeteners but many refuse to compromise on taste, as the food must have a desirable flavor (Gerdes, 2012; Cernivec, 2014; Li et al., 2014; Oltman et al., 2015). Contrary to this, many consumers still will choose a "naturally sweetened" product over an "artificial" labeled product (Li et al., 2015a; Oltman et al., 2015).

Additional consideration must be given to stability and cost before sugar can be substituted. There is a large cost difference between natural and artificial sweeteners; saccharin is currently the cheapest sweetener on the market at about $\$ 3 / \mathrm{lb}$., which is even cheaper than sugar $(\$ 0.27 / \mathrm{lb}$.) when considering its sweetness potency. Natural nonnutritive sweeteners are currently much more expensive: monk fruit is about $\$ 329 / \mathrm{lb}$. and stevia is about $\$ 130 / \mathrm{lb}$. Stability is another factor of sugar reduction. Many artificial sweeteners cannot be used in certain applications due to heat or $\mathrm{pH}$ instability (Chattopadhyay et al., 2014). Even with some instability, due to their sweetener potency and similar temporal profile, artificial sweeteners are currently more common in the dairy industry for sugar reduction than natural nonnutritive sweeteners. However, artificial sweeteners are increasingly becoming less popular due to the "artificial" stigma and the changing landscape of food, and the use of the term "natural" is currently under FDA review (Bearth et al., 2014; FDA, 2016b).

\section{Nonnutritive Sweeteners}

Whether natural or artificial, sugar reduction in dairy foods has been most successful by replacing sugar with nonnutritive sweeteners. This can be attributed to the fact that nonnutritive sweeteners are able to give the sweet taste desired by consumers without added calories (Yebra-Biurrun, 2005). Nonnutritive sweeteners are at least 30 to 20,000 times sweeter than sugar and, because such small amounts are required to reach equal sweetness compared with sucrose, manufacturers of nonnutritive sweeteners can label these products as "sugar free" or "reduced calorie" (Mitchell, 2007; Zygler et al., 2011). Nonnutritive sweeteners are currently consumed by at least $28 \%$ of the American population and are ubiquitous in many food products, including beverages, ice cream, chewing gum, chocolate, jams/jellies, yogurt, and salad dressings (Shankar et al., 2013; Antenucci and Hayes, 2014).

The ideal nonnutritive sweetener is a safe and stable molecule with high potency that gives the perception 
of sweet taste without compromising quality or palatability (Behrens et al., 2011). The goal of identical sweet taste is difficult because nonnutritive sweeteners have a sensory temporality different to that of sugar. Temporality is defined as how flavor or taste intensities and sensations of a food product change over time (Ott et al., 1991; Hanger et al., 1996; Fujimaru et al., 2012). Many different types of nonnutritive sweeteners exist but none of the nonnutritive sweeteners currently on the market is able to perfectly match the temporality of sucrose (Lawless and Heymann, 2010; Palazzo et al., 2011; Morais et al., 2014; Zorn et al., 2014; Azevedo et al., 2015). Nonnutritive sweeteners can also contribute other sensory attributes, including metallic mouthfeel and bitter taste.

\section{CHEMISTRY OF SWEET PERCEPTION}

\section{Sweet Taste Receptors}

Taste perception occurs in taste receptor cells, which are scientifically classified as modified epithelial cells. Taste receptor cells are packed densely into taste buds located on the surface of the tongue and soft palate, with up to 100 epithelial cells forming a single taste bud (Collings, 1974; Lindemann, 2001). In these taste buds, humans have the ability to detect sweet, salty, sour, bitter, or umami tastes, but the mechanism of reception for each of these tastes varies (Lindemann, 2001; Margolskee, 2002; Scott, 2005; Bachmanov and Beauchamp, 2007; Lawless and Heymann, 2010).

Sweet taste is believed to be perceived by G-protein coupled receptors (GPCR); specifically, sweet taste receptor subunits (Behrens et al., 2011). Each GPCR has a large amino-terminal ectodomain with an area similar in appearance to a "Venus-Flytrap" domain (VFTD), searching for something to bind. The VFTD likely contains multiple binding sites for different sweet molecules called T1R2 and T1R3. The higher affinity a molecule has to the binding site, the greater the intensity of sweetness perceived (Servant et al., 2010; Behrens et al., 2011). Sweeteners not only bind with different affinities but bind on different spots on the T1R2 and T1R3 receptors and many are characterized by a lingering sweet aftertaste (DuBois and Lee, 1983; Meyers and Brewer, 2008). Both of these facts explain why nonnutritive or artificial sweeteners taste so sweet compared with sucrose (Meyers and Brewer, 2008; Nie et al., 2008). For example, aspartame is known for a slight delay in onset of sweetness and with moderate lingering sweetness in the aftertaste, whereas stevia is known for delayed onset of sweetness and a long, lingering sweet and bitter aftertaste (DuBois and Prakash, 2012; Morais et al., 2014; Zorn et al., 2014).
Some sweeteners additionally contribute other sensory attributes, such as bitter taste or metallic sensation. This sensation may be a taste caused by the sweetener's ability to interact with multiple binding sites within the taste receptor (Allen et al., 2013); others have described it as a mouthfeel or trigeminal response, and more recently, an aromatic involvement was proposed (Waldrop and Ross, 2014; Skinner et al., 2017). Sucralose, stevia, and other nonnutritive sweeteners are generally documented to elicit a metallic sensation. Bitterness is another common problem with nonnutritive sweeteners, and food producers try to mask this by blending sweeteners (Pinheiro and Oliveira, 2005).

\section{The Role of Matrix on Sweet Taste}

Texture and fat in the food matrix play an important role in sugar-reduction studies because both highly influence sweet taste perception. Several studies have been conducted to identify the relationship between texture and flavor, but very few have been able to accurately define the relationship, primarily because so many relationships exist (Baines and Morris, 1987; Wilson and Brown, 1997; Malone et al., 2003; Di Monaco et al., 2014). Baines and Morris (1987) reported that the perceived intensity of flavor and sweetness was independent of guar gum concentrations up to $c^{*}$, where $\mathrm{c}^{*}$ is defined as the critical concentration that marks the transition from a dilute solution of random coil polymers to an entangled network of overlapping hydrodynamic volumes at high polymer concentration, and food polymers are proteins, polysaccharides, or peptides. At guar gum concentrations above $c^{*}$, perceived flavor and sweetness decreased steeply. Baines and Morris (1987) hypothesized that this was due to inefficient mixing that inhibited transport of tastant molecules, causing a sweetness and flavor reduction once the critical overlap concentration was surpassed. Practically speaking, the effect of viscosity on taste/ flavor is unclear, but clear suppression occurs at $\mathrm{c}>$ $c^{*}$. Particles are not entrapped until $\mathrm{c}^{*}$ is exceeded. In summary, at higher viscosities, it is harder to perceive sweet taste, so thicker foods require higher concentrations of sugar to obtain equivalent sweetness (Baines and Morris, 1987). Wilson and Brown (1997) found that the higher the concentration of gelatin, the more panelists had to chew the samples. This prolonged exposure resulted in lower intensity of flavor but in addition gave a prolonged perception of the flavor. This model suggests that the longer a consumer has to chew a sample, the longer the flavor lasts but at much lower intensities. Malone et al. (2003) reported that knowledge of in-mouth behavior of food microstructures and flavors could be used to design food product micro- 
structures to control flavor release and perception. For example, as more components are added to a food or as the complexity of a food increases, the perception of acidity decreases (Malone et al., 2003). Based on the Malone et al. (2003) hypothesis, reduced-sugar dairy foods can be designed to mimic full-sugar products because a reduced-sugar dairy food can be designed to control flavor release and sweetness perception to taste like a full-sugar product.

All these models can be applied to understanding dairy foods in terms of sugar reduction. For example, chocolate milk is a complex, viscous food matrix and, based on the models above, adjusting viscosity might enable some sugar reduction (Arabie and Moskowitz, 1971). Iso-sweetness of monk fruit in water compared with skim chocolate milk was determined by magnitude estimation scaling; the reported exponents for monk fruit in water and skim chocolate milk were 0.80 and 0.68 , respectively ( $\mathrm{Li}$ et al., 2015a). The higher the exponent, the more sweetening power a solution has. Sweeteners in water have a higher sweetening power than sweeteners in chocolate milk, which is consistent with the previous studies (Drake et al., 2011; Li et al., 2015a, b). Additionally, although thicker foods are perceived as less sweet, there is a prolonged flavor exposure time throughout oral processing (Wilson and Brown, 1997; Di Monaco et al., 2014). Staying with the chocolate milk example, chocolate flavor will be perceived longer in a thicker food. All of these studies reveal that maximum sweetness intensity depends not only on the temporal properties of the sweeteners, but also on its textural properties (Bayarri et al., 2007).

Sweet taste can be further hindered by other components of the food matrix besides viscosity, such as a higher fat content (Malone et al., 2003). Fat plays a critical role in the perception of sweet taste and, in general, solutions are perceived to be less sweet in emulsions with higher fat content (Bayarri et al., 2006; Zahn et al., 2013). Bayarri et al. (2006) suggested that the lower perception of sweet taste in an emulsion might be triggered by some trigeminal sensation that leads to a decrease in taste perception. Hoppert et al. (2012) found that trained panelists had higher sensitivity to sweetness differences at higher fat content. Therefore, chocolate milks with higher fat content require higher sugar contents to be perceived as iso-sweet, and if the chocolate milk is a high-fat food, regular consumers of the product will be highly sensitive to a reduction in sugar. The same principle could be applied to ice cream, yogurt, or any dairy product, suggesting that sugar reduction in higher fat foods may be more challenging.

\section{MILK AND SUGAR}

\section{Lactose}

Lactose, a disaccharide naturally present in milk, is an inherent part of mammalian milks and can be found in goat, cow, human, and all other animal milks. Lactose is exclusively found in milk and not found naturally in any plants or plant products (Schaafsma, 2008). Lactose is 9.4 times less sweet than standard sucrose but when it is hydrolyzed into glucose and galactose, the combination is only 1.5 times less sweet than sucrose (Pangborn, 1963). Flavored milks, as such, have sugar added to increase the flavor and overall sweetness, and the acceptability.

Lactose accounts for about $30 \%$ of the caloric value of whole milk but provides little sweetness (American Society for Clinical Nutrition, 1988). Lactose is formed when one glucose molecule is converted to uridine diphosphate (UDP)-galactose and then combined with an unmodified glucose that contains a $\beta-1-4$ glyosidic linkage in the mammary glands or udder of the mother cow (Schaafsma, 2008). Lactose is unique in that it only exists in its free form in milk, where it is unattached to any other molecule (Boyer, 2002). Lactose is the single most abundant milk solid particle and an important starting material for probiotic bacteria (Mazza, 1998). Many manufactures add lactose to baby formula so that formula-fed infants still get probiotic growth in the gut (Mazza, 1998). As consumers age, lactose continues to be a substrate for the bacteria in the gut but many consumers develop hypolactasia or lose the ability to digest lactose as they grow older (Keusch et al., 1969; Sahi et al., 1983; Tadesse et al., 1992; Rasinperä, 2004; Troelsen, 2005). Lactose-intolerant individuals have a deficiency of lactase, the enzyme needed to break down lactose, which is believed to be caused by polymorphisms across the $50-\mathrm{kb} L C T$ gene (lactase nonpersistence; Bhatnagar and Aggarwal, 2007; Ingram et al., 2009). Without lactase, the lactose becomes food for gas-producing bacteria in the gastrointestinal (GI) tract, leading to GI distress, including bloating, abdomen pain, and diarrhea (Zadow, 1986; Boyer, 2002). In America, 6 to $25 \%$ of Caucasians and 45 to $81 \%$ of African Americans, Asians, and Hispanics suffer from lactose intolerance (Baadkar et al., 2014; Abbasi and Saeedabadian, 2015). Lactose intolerance is defined as experiencing the symptoms defined above $30 \mathrm{~min}$ to a few hours after consuming dairy products. Discomfort can vary widely across individuals and there are currently no set limits for what defines lactose intolerant from not lactose intolerant (Cook and Dahlqvist, 1968; Suarez et al., 1995; Ingram et al., 2009). 
Table 2. Lactose content of various dairy products and ingredients

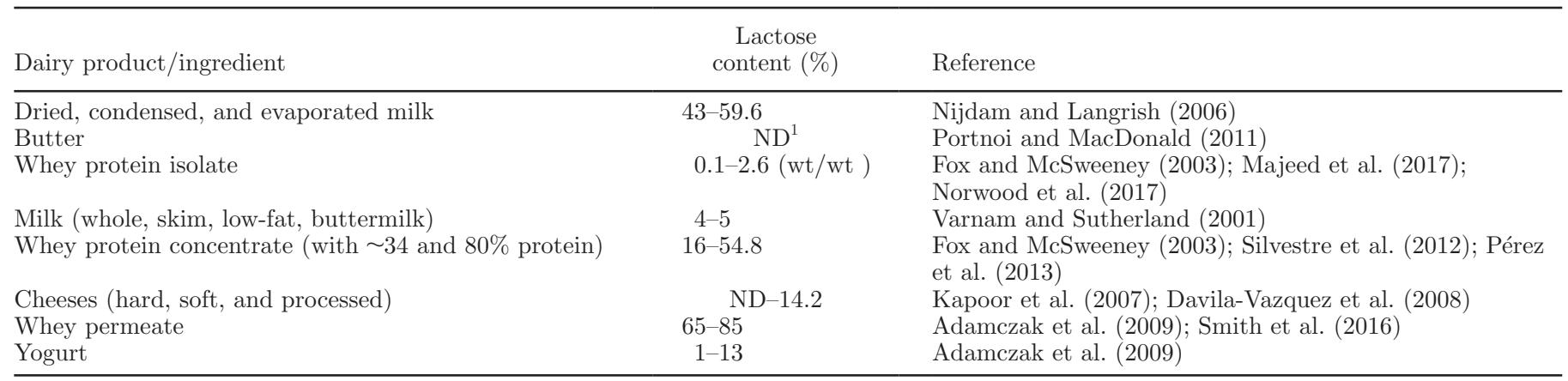

${ }^{1}$ Not detected.

It is important to note that lactose intolerance is not a milk allergy. Lactose intolerance is the inability to break down lactose, which causes GI discomfort. A milk allergy is an immune system response to milk protein that occurs after a person consumes milk (FARE, 2013; FDA, 2015b). Allergies can only occur in the presence of proteins. In the case of milk, a person can be allergic to casein protein, whey protein, or in some cases both. Milk allergy is the most common allergy among children, affecting approximately $2 \%$ of children under the age of $4 \mathrm{yr}$, but milk allergy is uncommon among adults, with only 0.1 to $0.3 \%$ with confirmed cases in adults (Woods et al., 2001; Rona et al., 2007). Sugar reduction in milk and lactose intolerance do not affect consumer allergies or sensitivities to milk protein.

\section{Status of Lactose in Different Dairy Products and Dairy Ingredients}

The lactose content in dairy products varies greatly (Table 2). The lactose content in bovine milk, including whole, skim, low fat, buttermilk, and flavored milks, ranges from 4.2 to 5\% (Varnam and Sutherland, 2001). Spray-dried milk powders contain higher amounts of lactose on a weight basis compared with fluid whole or skim milk (43-59.6\% lactose) due to water removal (Nijdam and Langrish, 2006). Other dairy products contain lower percentages of lactose. Butter is a high-fat dairy product that contains only trace amounts of lactose (Portnoi and MacDonald, 2011). Cheeses can have a large range of lactose, ranging from as low as nondetectable to as high as $14.2 \%$ in some process cheeses (Kapoor et al., 2007; Davila-Vazquez et al., 2008). Hard cheeses have low levels of lactose because much of the lactose is removed with the liquid whey during the cheese-making process (Ramchandran and Vasiljevic, 2012). Because soft cheeses do not undergo the same cheese-making process as hard cheeses, they have a higher lactose content. Yogurt mix contains about 6 to $8 \%$ lactose after pasteurization, but concentrations decrease during fermentation, typically to $4.6 \%$ or less 45 min after inoculation. The yogurt culture ingests the lactose and continues to break it down to 1 to $5 \%$ at the end of fermentation (Wolf et al., 2015).

Whey protein isolate (WPI) contains less lactose than whey protein concentrate (WPC) with $\sim 34 \%$ protein (0.1-2.6\% and $54.8 \%$ respectively, Table 2; Silvestre et al., 2012; Norwood et al., 2017). In contrast, whey permeate is a high-lactose dairy ingredient produced as a by- or co-product of whey protein manufacture and contains mostly lactose $(65-85 \%)$ and minerals (Adamczak et al., 2009; Frankowski et al., 2014; Smith et al., 2016).

\section{GENERAL METHODS OF SUGAR REDUCTION}

\section{Lactose Hydrolysis}

Lactose hydrolysis is a method for sugar reduction in dairy foods. Currently, enzymatic lactose hydrolysis is used to make lactose-free milk (Fox and McSweeney, 2003; Harju et al., 2012). The FDA has not yet set a definition for the terms "lactose-free" or "lactosereduced," in dairy products (FDA, 2015b). However, food manufacturers must label products truthfully. A lactose-free product should not contain lactose, and lactose-reduced product must have a meaningful reduction (FDA, 2015b). Although the importance of lactose hydrolysis in dairy products has been known for decades, it has only been within the past few years that industrial production of $\beta$-galactosidase became feasible (Abbasi and Saeedabadian, 2015).

Lactose hydrolysis can be done many ways. Singleuse hydrolysis is performed 2 ways: the first method consists of adding $\beta$-galactosidase to pasteurized milk and holding the mixture at 35 to $45^{\circ} \mathrm{C}$ for a set amount of time or by holding it overnight at refrigeration temperatures (Zadow, 1986). The lactase enzyme is then deactivated by an additional heat treatment. The second method for lactose hydrolysis can be achieved by 
adding a sterile lactase to UHT milk before packaging. In this method, lactose is broken down during the first few days of packaging. Both single-use enzyme methods are costly (Panesar et al., 2010). More cost-effective lactose hydrolysis methods include membrane recovery of soluble enzyme or immobilized systems (Zadow, 1986). In the membrane recovery system, the enzyme is added to milk permeate after ultrafiltration and the enzyme can then be recovered by filtration and reused. The hydrolyzed lactose permeate is then reintroduced into the milk (Zadow, 1986).

Lactose hydrolysis has been investigated as a sugar reduction alternative because hydrolysis of $70 \%$ of the lactose in milk increases the sweetness of milk or yogurt to the same degree as adding $2 \%$ sugar would (Zadow, 1986; Mahoney, 1998; Adhikari et al., 2010). Lactose-free milk is sweeter than regular milk (Jelen and Tossavainen, 2003; Adhikari et al., 2010; Skryplonek et al., 2017). Li et al. (2015b) investigated the effect of using lactose hydrolysis to sweeten chocolate milk naturally. The sweetness achieved from hydrolysis of lactose naturally present in the milk was not sufficient to sweeten chocolate milk to a palatable level. The authors suggested that this method might be more successful in a simpler flavored milk than in chocolate milk because cocoa is inherently bitter and requires more sugar than vanilla or strawberry milk ( $\mathrm{Li}$ et al., 2015b). Li et al. (2015b) additionally investigated the effect of adding lactose directly through the addition of a permeate followed by hydrolysis. The addition of the permeate powder created an overwhelming salty taste because of the minerals in permeate, which made this an unsuitable approach to sweeten chocolate milk (Li et al., 2015b). Lactose hydrolysis of natural lactose in milk has also been investigated as a means of sugar reduction in yogurt (Engel, 1973; Tamime and Deeth, 1980). Hydrolysis of lactose in yogurt leads to a milder, sweeter yogurt without added sugar (Engel, 1973). Whalen et al. (1988) reported that consumers could not detect a difference between yogurt sweetened with sugar ( $4 \mathrm{~g}$ of sucrose/100 g of yogurt) and lactose-hydrolyzed yogurt with less sugar added (2-3 g of sucrose/100 g of yogurt; $\mathrm{n}=25, P<0.01$ ). This approach (lactose hydrolysis) is applied for modest sugar reduction in yogurt today.

Lactose hydrolysis has also been used to reduce sugar content in ice cream either by hydrolyzing lactose in ice cream mix or by using lactose-free skim milk powders (Abbasi and Saeedabadian, 2015). El-Neshawy et al. (1988) found that lactose-reduced reconstituted skim milk resulted in a decrease in the formation of a sandy texture in reduced-sugar ice cream and improved the textural properties. Sandy texture in ice cream is an undesirable characteristic caused by large lactose crystals (Arbuckle, 1972). Large lactose crystals form in ice cream due to the low solubility of lactose. When the available free water freezes in the ice cream mix, high concentrations of lactose are left behind to form large crystals (Skryplonek et al., 2017). El-Neshawy et al. (1988) recommended hydrolysis of $75 \%$ of the lactose in skim milk powder to prevent formation of the sandy texture and reduce sugar content by 12.5 to $25 \%$. Abbasi and Saeedabadian (2015) implemented this finding and found that lactose hydrolysis at the suggested $75 \%$ level increased the apparent viscosity of the ice cream mix, lowered the freezing point, increased the sweetness, lowered sandiness, and improved the overall acceptability of ice cream. In this study, lactose hydrolysis of milk led to a $25 \%$ reduction in sugar content of ice cream.

\section{What Happens to Label Declaration When Lactose is Hydrolyzed?}

There is currently a debate over whether lactase is considered a processing aid or whether it must be declared as an ingredient on food labels (FDA, 2004, 2015c). Processing aids are substances approved by both the FDA and the USDA that are not present in significant amounts in the finished product and do not affect the appearance or taste of the final product (USDA, 2008). As stated earlier, it is impossible to hydrolyze all of the lactose in the product; therefore, in lactose-free milk such as Lactaid (McNeil Nutritionals LLC, Ft. Washington, PA) and Fairlife (Fairlife LLC, Chicago, IL, and The Coca Cola Company, Atlanta, GA), additional lactase is added into the packaged product to break down the remainder of the lactose present in the milk before consumption (Jelen and Tossavainen, 2003). These products declare "lactase enzyme" as an ingredient because some lactase is never deactivated by heat and this type of lactose-free milk must declare lactase on the label. The FDA considers this an added ingredient and it must be declared on the label (USDA, 2008). However, if lactase is naturally produced by the body, does it need to be declared on the label? This dilemma is the subject of much debate. It is impractical, as stated in 21CFR101.100 (a) (3), to declare "incidental additives" (processing aids) in nonfunctional trace amounts; however, when present in active and functional amounts in the final product, it should be declared on the label. Additionally, consumer education is of vital concern. If some milks declare lactase as an added ingredient per the FDA definition and some are not required to declare lactase on the label, consumers become confused. This phenomenon creates large obstacles for the dairy industry when lactase is used as a method of sugar reduction in dairy foods. Education and consistency are important for consum- 
ers to understand how sugar-or lactose - reduction is being achieved.

\section{Ultrafiltration}

Ultrafiltration is a well-established method for decreasing lactose in milk (Jelen and Tossavainen, 2003); it is a pressure-driven process that separates compounds in milk by molecular weight. Ultrafiltration is widely used in the dairy industry for lactose removal and, in turn, can be used for sugar reduction. Heavier molecular weight compounds (protein, fat) are retained by UF, whereas the lower molecular weight compounds (lactose, water, minerals, and vitamins) pass through the membrane. Water can then be added back into the suspended solids to create lactose-free milk that is not sweet like lactose-hydrolyzed milk.

The final sweetness of UF-produced lactose-free milk can be improved through milk chromatography or by the addition of nonnutritive sweeteners (Jelen and Tossavainen, 2003; Harju et al., 2012). Milk chromatography, the process of separating lactose from milk without removing the salts, splits milk into 2 streams: a main stream and a secondary steam. In the main stream, where most of the milk goes, lactose is removed from the milk through ultrafiltration. In the secondary stream, lactose is hydrolyzed with enzymes. The 2 streams are then brought back together so that the sweetness of the final product matches that of regular milk (Jelen and Tossavainen, 2003; Harju et al., 2012). Ultrafiltered milk can also be improved through the addition of nonnutritive sweeteners following UF. This method of lactose removal has been investigated as a means of sugar reduction in yogurt and cheese (Kosikowski, 1979; Özer and Robinson, 1999; Magenis et al., 2006; Karam et al., 2013). The lactose is removed from the milk before further processing into yogurt or cheese.

\section{Direct Reduction}

Direct reduction of sugar is a method for a gradual reduction of sugar consumption (MacGregor and Hashem, 2014). The sugar content of dairy products is slowly and progressively reduced so that consumers will gradually get used to the lower sugar concentrations without noticing a difference (MacGregor and Hashem, 2014). This reduction can be achieved through threshold testing to determine what change in sugar concentration causes a perceivable change in sweetness intensity by $50 \%$ of consumers (Boring, 1946). This is also called a "just noticeable difference" threshold (JND). The calculated JND can then be used to determine gradual sequential sugar reductions of up to $30 \%$ that can be implemented without consumer awareness (Li et al., 2015b). This gradual reduction has been achieved in the United Kingdom in regards to salt reduction (MacGregor and Hashem, 2014). As a further example of the application of JND values to reduction of target ingredients, Drake et al. (2011) evaluated JND salt concentrations in different dairy matrices (cottage cheese, cheese sauce, and milk-based soup). They found that consumers were sensitive to salt reduction in dairy foods and noticed reductions at less than $20 \%$ in all the products tested. The JND values were different among the 3 dairy foods tested. However, if consumers were informed about the reduced sodium and its health benefits, overall liking scores were not significantly different between the regular and reduced-sodium options (Drake et al., 2011). Although JND values have not been investigated thoroughly in terms of sugar reduction in dairy foods, they could be a valuable option that should be explored. Harwood et al. (2013) recommended using rejection thresholds, or the point at which a consumer preference occurs for a sample not containing a substance, to see at what point a consumer will no longer accept a product for quality control and product optimization (Lawless and Heymann, 2010). In terms of sugar reduction studies, the rejection threshold is important to determine when a consumer will no longer purchase a product. The JND has been used for sugar reduction in dairy-based emulsions and chocolate milk (Hoppert et al., 2012; Oliveira et al., 2016). Hoppert et al. (2012) reported a matrix-specific sugar reduction; the higher the concentration of fat, the more sensitive a panelist is to a sugar reduction (i.e., lower JND value). Based on these studies on model foods, a modest sugar reduction of 5 to $20 \%$ may be possible by direct reduction (Hoppert et al., 2012; Oliveira et al., 2016). Even if consumers notice a difference in sweetness, the product in its sugar-reduced form may still be liked. Li et al. (2015b) reported that direct sugar reduction under $30 \%$ did not change consumer acceptance.

\section{Sugar Substitutions}

Because consumers desire sweet taste, sugar substitution is a preferred method among sugar reduction techniques to reduce calories while preserving sweet taste. Currently, many different types of sweeteners are available for sugar substitution (Table 3) but as stated earlier, many issues arise with sugar substitution, the most troublesome being that sugar substitution is very product specific. The relationship between the matrix and the concentration of sweetener to create an isosweet relationship cannot be consistently defined by any single model. Sugar substitution has been successfully done, however, in many products such as frozen 
MCCAIN ET AL.

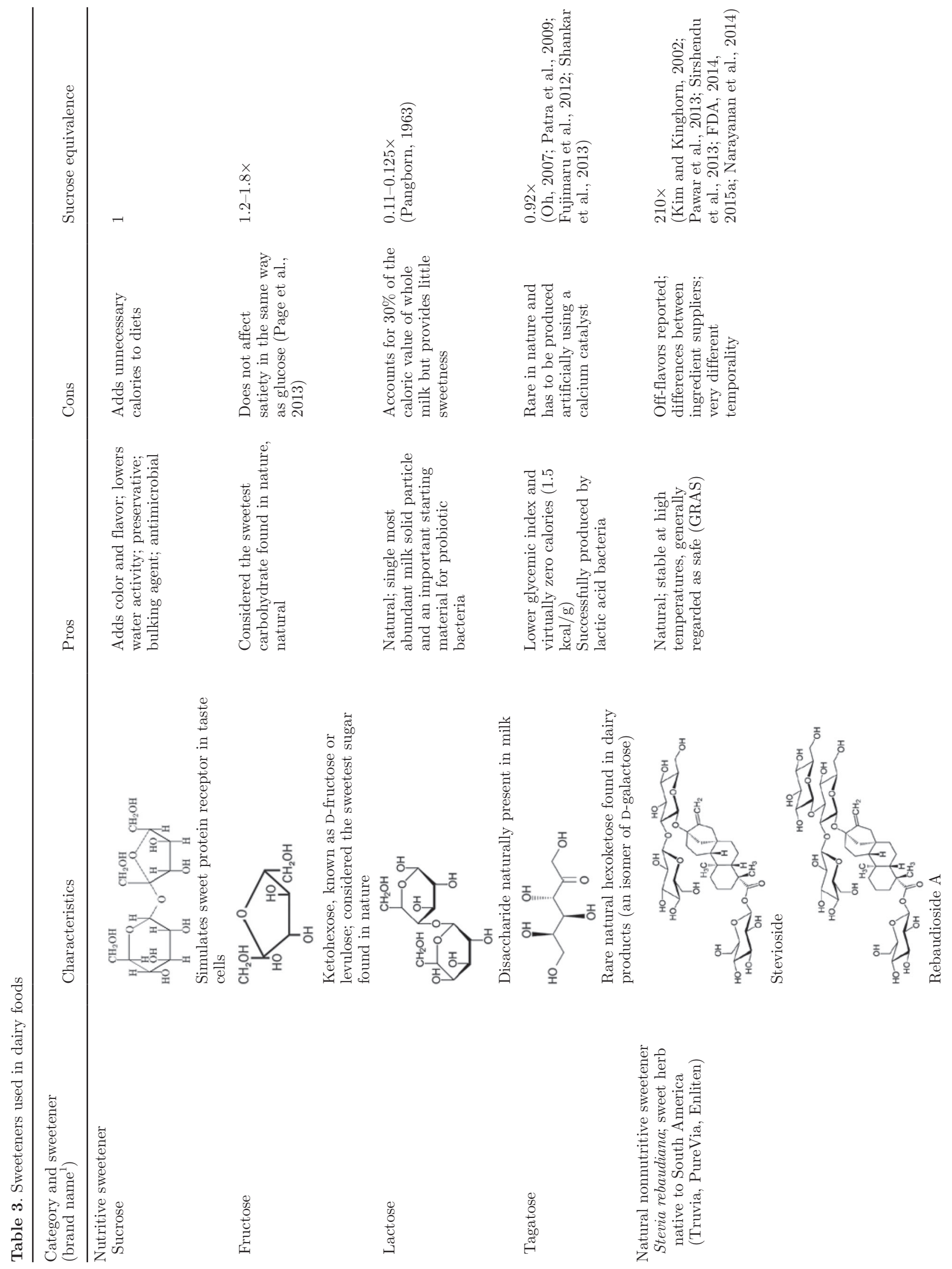


INVITED REVIEW: SUGAR REDUCTION

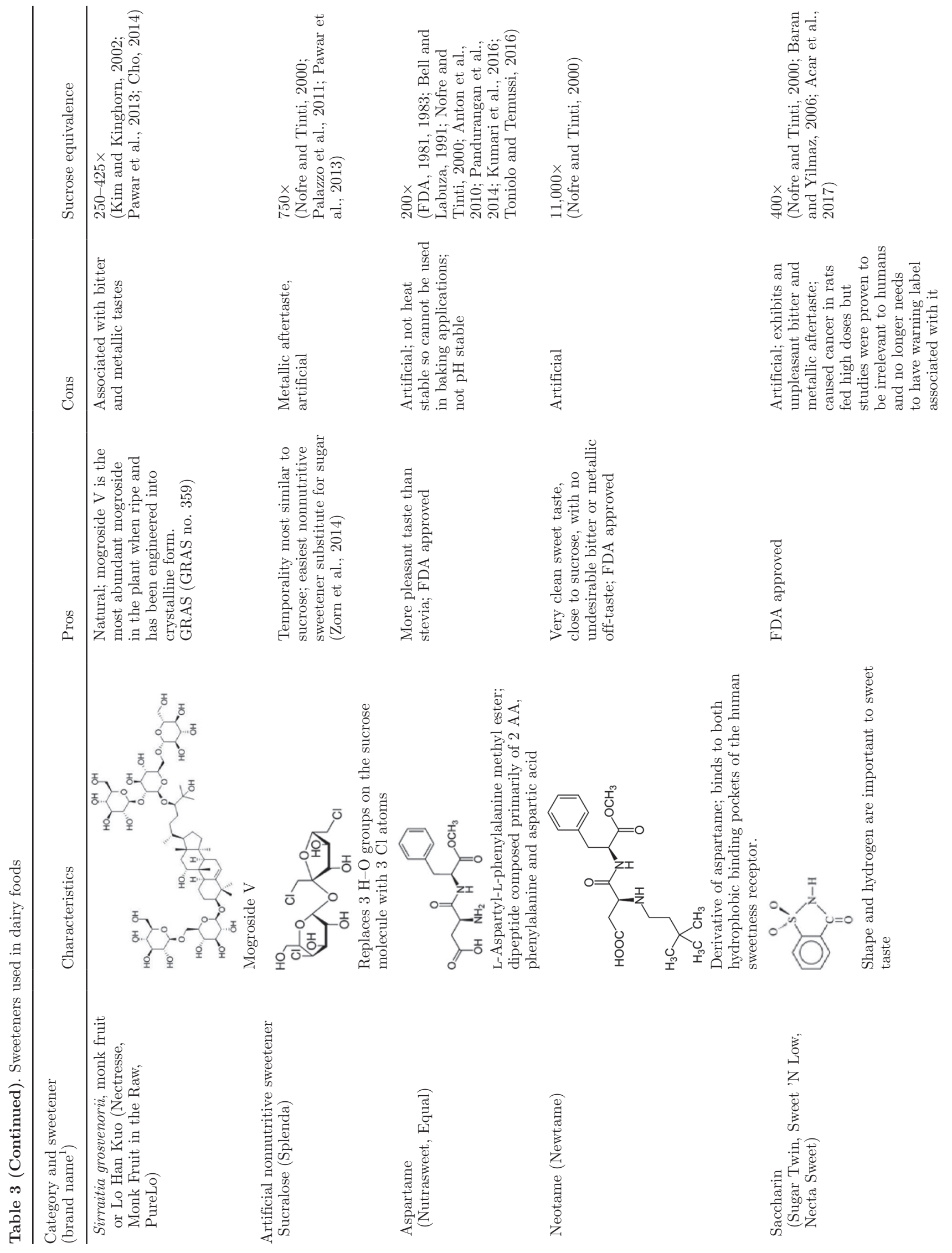

نัँّ 


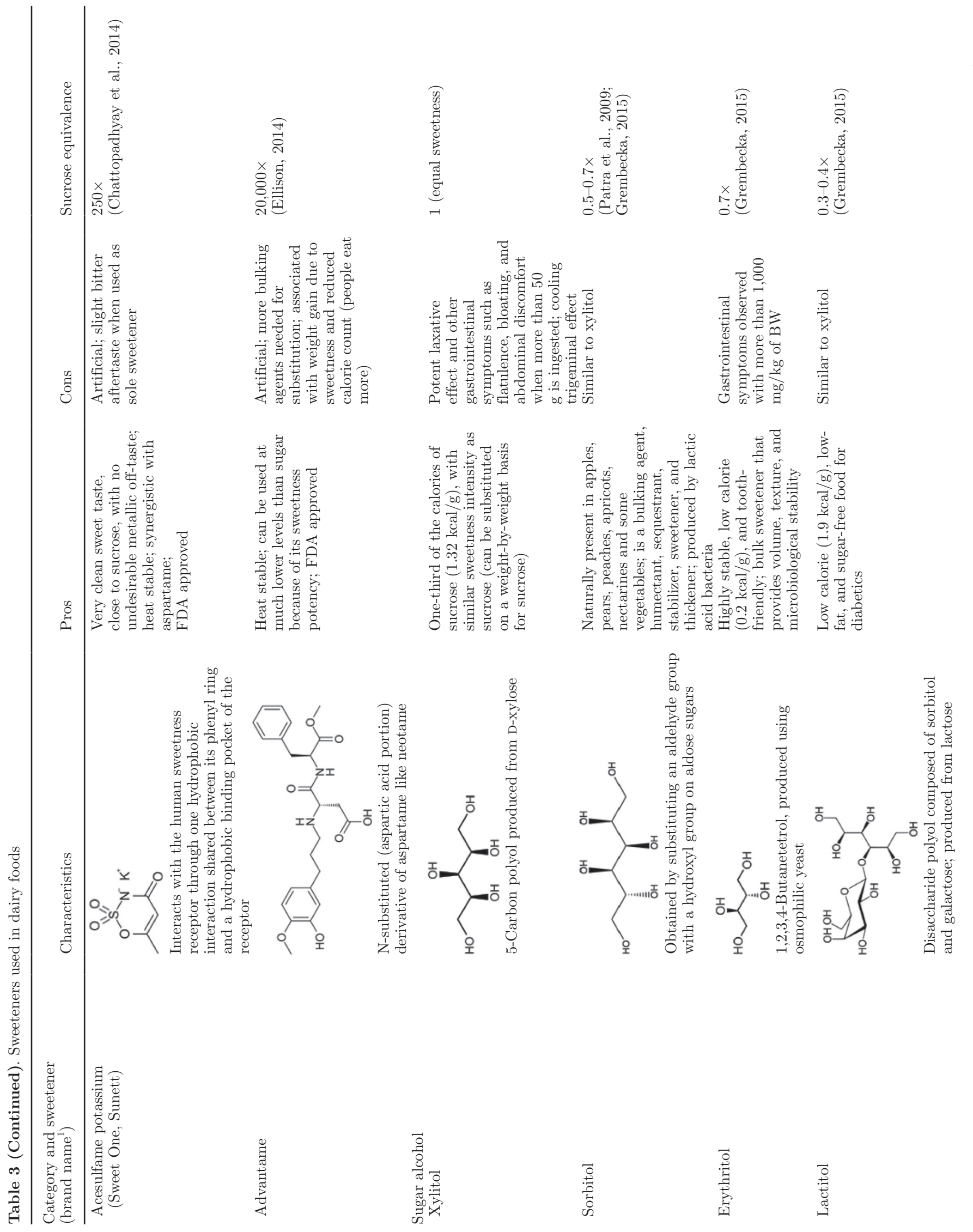




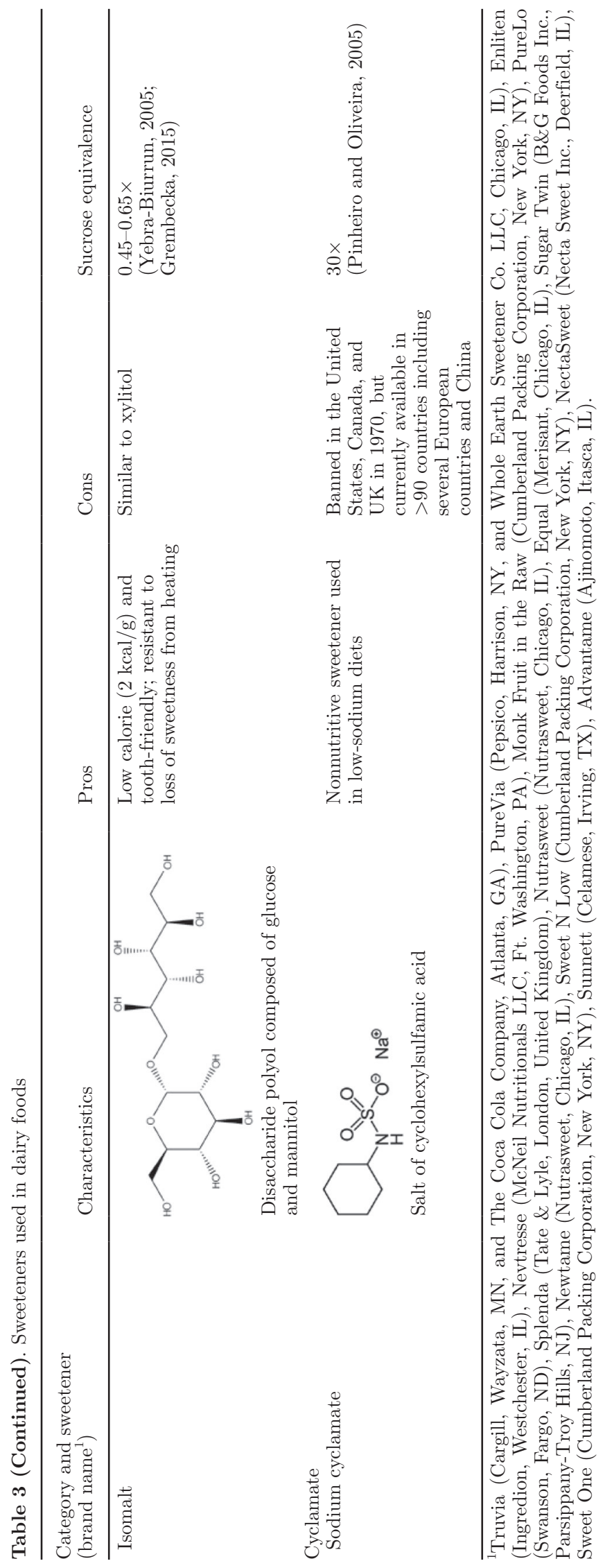

yogurt, yogurt, and chocolate milk. Isik et al. (2011) found that isomalt could be substituted for sugar in frozen yogurt for a similar sweetness and no added sugar. Narayanan et al. (2014) reported that stevia, at 0.7 to $5.5 \%$ (wt/wt) substitution concurrently with mildly sweet bulk fillers or some sucrose, could be used in naturally flavored vanilla low-fat yogurt. Guggisberg et al. (2011) investigated the effects of a total substitution of $8 \%$ sugar in yogurt with Actilight (a fructooligosaccharide; Tereos, Marckolsheim, France) combined with stevia and Palatinose (bene; Mannheim, Germany) and found that $6 \%$ Actilight combined with stevia lead to a temporality most similar to that of the sucrose control. Li et al. (2015a) also reported that chocolate milk could be partially sweetened with monk fruit and stevia to successfully reduce sugar and maintain sweet taste and a similar temporal sweetness profile.

\section{Formulation Challenges for Reduced-Sugar Dairy Products}

A reduction in sugar is easier to perceive than a reduction in fat or salt content, making formulation of reduced-sugar dairy products a challenge (Biguzzi et al., 2014). One critical challenge that makes these studies so inherently difficult is that the perceived intensity of the sweetener is entirely dependent upon the food matrix. Wilson and Brown (1997) and $\mathrm{Li}$ et al. (2015a, 2015b) reported that iso-sweet concentrations of sugar compared with different sweeteners differed when the viscosity of the matrix was increased. Biguzzi et al. (2014) found that a reduction in sugar content caused little change in perception of fat in biscuits, whereas a reduction in fat content sometimes induced a reduction in sweetness perception. This means that the relationship between the matrix and the concentration of sweetener to create an iso-sweet relationship cannot currently be consistently defined by any model. Therefore, there cannot be an overarching study for all nonnutritive sweetener substitutions; instead, each substitution is product specific. This issue makes sugar reduction in dairy foods challenging.

\section{SUGAR REDUCTION STUDIES IN DAIRY FOODS}

\section{Ice Cream}

Ice cream is one of the most heavily consumed dairy products in the world (Sun-Waterhouse et al., 2013). It is a highly complex food matrix that can be defined as an aerated suspension of fat and water in a concentrated sugar solution (Frøst et al., 2005; Erkaya et al., 2012). To achieve the sweet taste desired by consumers, a substantial amount of sugar needs to be added, rang- 
ing from 10 to $14 \%$ (Goff, 2015). Therefore, reducedsugar and reduced-fat products, such as ice cream, in general, tend to show a higher propensity for a bitter aftertaste and a lower intensity of creaminess (Cadena et al., 2012). Even with higher bitter tastes due to replacement by alternative sweetener, a $25 \%$ reduction in sugar was not linked to decreased consumer acceptance of vanilla ice cream (Cadena et al., 2012). Furthermore, Cadena and Bolini (2011) found that calorie-reduced ice creams sweetened with sorbitol and sucralose (with a sugar reduction of $3.4 \%$ ) were most accepted compared with other "light" vanilla ice creams or ice cream with a minimum reduction of $25 \%$ of the total energy, sugar, or lipid. Sugar substitutes such as sugar alcohols have also been investigated to reduce the sugar content of ice cream. Erythritol and lactitol are sugar alcohols that have been used to create low-calorie ice cream (Grembecka, 2015). Erythritol is more commonly used for sugar reduction in ice cream because it provides volume and texture and is only a fraction of sucrose calories $(0.2 \mathrm{kcal} / \mathrm{g})$.

Another hurdle in sugar reduction of ice cream is flavor. Chocolate-flavored ice creams are typically formulated with higher sugar content to decrease the bitterness associated with cocoa (Harwood et al., 2013). Guinard et al. (1996) found that the optimum level for sugar in vanilla ice cream was around $13.5 \%$ but other research has shown that chocolate ice creams had to have much higher sugar levels to compensate for the bitterness of cocoa (Prindiville et al., 1999). Marshall et al. (2003) suggested this higher level of sugar to be a 1:1 ratio of sugar to cocoa powder. Chocolate ice cream sugar reduction is thus difficult because of cocoa's bitterness and the decreased flavor perception that comes with sugar reduction (Guinard et al., 1996; Koeferli et al., 1996; Roland et al., 1999). When sugar is reduced in chocolate ice cream, not only does the ice cream taste more bitter, it also tastes less chocolatey (Prindiville et al., 1999). Harwood et al. (2013) proposed a solution to this problem by marketing sugar-reduced chocolate ice cream to dark chocolate lovers, who already desire and tolerate substantially higher levels of bitterness.

Fat reduction is another way the dairy industry is trying to decrease the energy density of ice cream. Fat reduction affects not only the mouthfeel of ice cream but can also lead to a change flavor release and possibly sweetness perception (Karaca et al., 2009). Prindiville et al. (1999) found that decreasing the fat content of chocolate ice cream increased its perceived sweetness. The study found that ice cream with $0.5 \%$ fat was significantly sweeter than other ice creams with 4.0, 6.0, and $9.0 \%$ fat because the fat was not present to impede exposure of sweetener to tongue (Malone et al., 2003). Conflicting research from Roland et al. (1999) reported that an increase in sweetness perception in vanilla ice cream when fat was used above $7 \%$. In turn, Rolon et al. (2017) found that, although there was a physical change in texture properties of vanilla ice cream when substituting maltodextrin for fat (6-14\% fat with 8-0\% maltodextrin, respectively), there was no change in sweetness perception of ice cream when using an untrained consumer panel. However, the trained panel did detect a sweetness difference among the different fat reduction treatments (Rolon et al., 2017).

Frozen yogurt is often viewed as a healthy alternative to ice cream because of its lower fat content and the presence of lactic acid bacteria, even when frozen (Lopez et al., 1998). The typical sugar content of frozen yogurt is around 10 to $14 \mathrm{~g} / 100 \mathrm{~g}$, which is about the same amount of sugar as ice cream (14 g/100 g; Marshall et al., 2003). Skryplonek et al. (2017) investigated lactose hydrolysis in frozen yogurt to increase solubility of lactose, increase sweetness of the yogurt, and expand the availability of frozen yogurt to lactose-intolerant individuals. When a trained panel compared the lactosehydrolyzed frozen yogurt with the control, they noted that the lactose-hydrolyzed yogurt was creamier and sweeter. Isik et al. (2011) reported that substituting inulin and isomalt for sugar and fat in frozen yogurt led to a similar sweetness and a reduction in fat with no added sugar.

\section{Yogurt}

Yogurt is a popular product in the United States, helping the dairy industry gross more than $\$ 125$ billion a year (IDFA, 2017). Yogurt is generally recognized as a healthy food because of its nutritional content but it is generally sweetened with sugar to increase palatability (Guggisberg et al., 2011). Yogurt is made when the lactic acid-producing bacteria Streptococcus thermophilus and Lactobacillus bulgaricus are added to cream, milk, or skim milk when lactose is present (21CFR131.200; https://www.accessdata.fda.gov/scripts/cdrh/cfdocs/ cfcfr/CFRSearch.cfm?fr=131.200). The bacterial culture ferments the lactose present in the milk to lactic acid, causing the milk to thicken, and it gives yogurt its characteristic sour taste (Tamime and Deeth, 1980; Harper et al., 1991). The first step to making yogurt is mixing all the ingredients - milk, flavoring, and sugarto make a milk base. Sugar, up to $5 \%$, is added to the milk base before homogenization, heat treatment, and incubation/fermentation (Tamime and Deeth, 1980; Sodini et al., 2010). The sugar is added to yogurt to lessen the effect of sour taste due to the production of acids and acetaldehyde in yogurt by the bacteria (Harper et al., 1991). The bacteria ferment about 40 to $50 \%$ of the lactose in the yogurt mix (Alm, 1982). 
Several studies have reported that yogurt liking is influenced by texture, aroma, and taste (Kälviäinen et al., 2003; Bayarri et al., 2011; Routray and Mishra, 2011; Desai et al., 2013; Grygorczyk et al., 2013). Sweetness is a major driver of liking for yogurt and yogurt-like products (Bayarri et al., 2007; Thompson et al., 2007); consumers find yogurt without any added sugar to be too sour (Harper et al., 1991). Allgeyer et al. (2010) found that consumers preferred drinkable yogurts with a medium level of sweetness and high viscosity. Hoppert et al. (2013) reported that sugar content (112 vs. $160 \mathrm{~g} / \mathrm{kg}$ ) had a significant effect on the overall liking of the yogurt when investigating different types of dietary fibers in the yogurt. The group found that higher sugar content lead to higher overall liking. However, Hoppert et al. (2013) did find that many consumers rated the regular-sugar products as being too sweet and flavor as too low and that increasing the flavor of sugar-reduced yogurt could lead to better hedonic scores. Yoo et al. (2017) additionally suggested that sugar reduction was positively perceived by children and adolescents as both had an increase in expected overall liking scores when primed with a sugar reduction claim. Chollet et al. (2013) found that although consumers preferred yogurts with $10 \%$ sugar, they found yogurt containing $7 \%$ sugar acceptable.

Nonnutritive sweeteners were additionally investigated as a means of sugar reduction in yogurt. Pinheiro and Oliveira (2005) reported that it was possible to produce a probiotic yogurt successfully using sweeteners (sucrose, aspartame, aspartame + saccharin, and sucralose) without affecting the viability of the probiotic microorganisms. The addition of nonnutritive sweeteners did not negatively affect the yogurt-making process because the sweeteners did not break down over time (Pinheiro and Oliveira, 2005). Sweetener blends of nonnutritive sweeteners have been very successful in reducing sugar content of yogurt (Gelardi, 1987; Birch, 1996; Hanger et al., 1996; Pinheiro and Oliveira, 2005; Waldrop and Ross, 2014; Narayanan et al., 2014; Guggisberg et al., 2011).

\section{Flavored Milk}

Flavored milk continues to gain popularity among children and adults because of its special taste and its ability to meet the dietary requirements for dairy foods in the United States (IDFA, 2010). Chocolate milk is the most popular flavored milk for both children and adults in the United States (Thompson et al., 2004, 2007). To be considered chocolate milk, the chocolate flavoring must meet the standard of identify of cacao products as defined by 21CFR163. Studies have shown that flavored milk increases milk consumption; there- fore, chocolate milk plays an important role in getting Americans to consume the recommended 3 cups of milk per day (Murphy et al., 2008; Li et al., 2015b; USDAHHS, 2015). Yon et al. (2012) found that, on average, students in grades 3 to 5 consumed about 5.5 oz. of flavored milk per day and that elementary students were just as likely to drink lower-calorie flavored milk as regular milk. Li and Drake (2015) pointed out that the Yon et al. (2012) study did not use a huge calorie reduction so the flavor differences were likely small and most likely not detected by children. In May 2017, US Secretary of Agriculture Sonny Perdue signed an interim rule to bring $1 \%$ chocolate milk back to the $\mathrm{Na}$ tional School Lunch Program (NSLP). Previously, only unflavored low-fat milk or flavored and unflavored skim milk was allowed in elementary or secondary schools as part of the NSLP (8 and 12 oz., respectively; American Heart Association, 2017).

Despite having similar nutritional benefits as regular fluid milk, chocolate milk is known for a higher sugar content; thus, chocolate milk is a large target for sugar reduction techniques (Johnson et al., 2002; Murphy et al., 2008). From 2006 to 2010, there was a decrease in the calories of chocolate milk from 165.9 to 154 (Van Horn et al., 2010). However, sugar reduction of chocolate milk is quite costly and many school directors choose the higher sugar alternative to reduce cost or choose to eliminate chocolate milk entirely (Van Horn et al., 2010; Li and Drake, 2015). Quann and Adams (2013) found that eliminating chocolate milk from schools resulted in a $37.4 \%$ decrease in milk consumption. Furthermore, when chocolate milk is removed from a child's diet, 3 or 4 additional foods needed to be added into the diet to replace the nutrients from milk, adding additional calories (16 to $141 \mathrm{kcal})$ and cost $(\$ 2,200$ to $\$ 4,600$ annually per 100 students; Quann and Adams, 2013). Therefore, sugar-reduced product should be considered the cheaper alternative.

Chocolate milk has many factors that influence consumer choice. Kim et al. (2013) reported that fat content and sugar content (or intrinsic factors) were the biggest drivers of choice for adult consumers of chocolate milk and had a significant effect on consumer purchase habits. This study found that consumers were more likely to purchase chocolate milk based on intrinsic factors (fat and sugar contents) than on extrinsic factors (brand name and packaging labels) especially when the consumers were able to taste the milk. Additionally, an "organic" label had a positive influence on consumer satisfaction of chocolate milk even if it did not directly correlate to higher purchase intent (Kim et al., 2013). Thompson et al. (2007) reported that having a "natural" chocolate flavor was the most important attribute for Hispanic and Caucasian adult consumers 
when choosing chocolate milk. Thompson et al. (2004, 2007) also found that sweet taste was a driver of liking but many adult consumers reported commercial chocolate milk to be too sweet. Li et al. (2014) reported that parents preferred natural nonnutritive sweeteners over nutritive sweeteners as the sweetener source in chocolate milk. However, adults preferred both nutritive and natural nonnutritive sweeteners over artificial nonnutritive sweeteners in chocolate milk. Kim et al. (2013) found that although consumers were aware of lower fat and lower sugar products, most still preferred a higher calorie product due to taste. Childs and Drake (2009) reported a similar phenomenon with fat replacement; even if a consumer knows an alternative food is better for them, some consumers do not want to sacrifice flavor while seeking lower fat alternatives. $\mathrm{Li}$ and Drake (2015) predicted that the innovation of calorie-reduced chocolate milk with natural sweeteners should help increase milk consumption while increasing sugar reduction. Because there are known off-tastes associated with natural nonnutritive sweeteners, $\mathrm{Li}$ et al. (2015a) investigated adult and child acceptance of chocolate milk using blends of sucrose and nonnutritive sweeteners. Young adults and children found chocolate milks with $25 \%$ monk fruit with sucrose and $25 \%$ stevia with sucrose $(9.39 \mathrm{~g} /$ serving of sucrose and $10.8 \mathrm{mg} / \mathrm{L}$ monk fruit or $7.09 \mathrm{mg} / \mathrm{L}$ stevia) to be acceptable ( $\mathrm{Li}$ et al., 2015b). However, greater substitutions of stevia or monk fruit were not as well liked. Li et al. (2015b) reported that added sugar could be directly reduced in chocolate milk [16.8 g of sugar/serving (benchmark control) to $13.3 \mathrm{~g}$ of sugar/serving] and still be accepted by children and adults as long as it did not exceed $30 \%$.

Oliveira et al. (2016) investigated a direct sugarreduction strategy with chocolate milk using JND values in Uruguay. The group reported that consumers could detect a sugar reduction of approximately $6.00 \%$ (24.41 g of sucrose $/ 240 \mathrm{~mL}$ ). However, Li et al. (2015b) reported that even though consumers could detect small differences in sweetness in chocolate milk, milks that did not exceed a 30\% reduction in sugar were still liked. Consumers reported a noticeable difference in the sensory attributes of sweetness, bitterness, and chocolate flavor in chocolate milk (Oliveira et al., 2016). Interestingly, Harwood et al. (2012) found that consumers who self-reported that they preferred dark chocolate had a higher bitterness rejection threshold (2.3 times) than consumers who preferred milk chocolate. However, there was no difference in bitterness detection threshold between consumers who preferred dark chocolate and those who preferred milk chocolate milk, suggesting that chocolate preference was not due to bitterness sensitivity. This may be a contributing factor to Oliveira et al. (2016) finding that even though consumers could detect a reduction in sugar at $6 \%$, a sugar reduction of $28.9 \%$ did not result in significant differences in overall liking of chocolate milk. This result is consistent with Oliveira et al. (2015), who reported that a $20 \%$ reduction in added sugar did not cause significant differences in liking in chocolate milk. Li et al. (2015b) also reported that sucrose reduction in chocolate milk for both children and young adults was possible as long as it did not exceed a $30 \%$ reduction (from $70.17 \mathrm{~g} / 240 \mathrm{~mL}$ ). Oliveira et al. (2016) suggested that sugar could gradually be reduced over time without a significant change in consumer liking (MacGregor and Hashem, 2014). This approach could be implemented for all commercial dairy products to make more healthful processed products that meet current nutritional recommendations (Oliveira et al., 2016).

\section{PRACTICAL APPLICATIONS}

Understanding current sugar-reduction techniques, research, and consumer response to sugar reduction in dairy products is important for dairy manufacturers to design and produce sugar-reduced products. Sugar reduction is an inherently difficult task due to the many functions of sugar in food products but progress is being made to make products acceptable to consumers. Currently, substitution of sugar using nonnutritive sweeteners has been the most successful approach for sugar reduction but direct reduction of sugar and lactose hydrolysis methods show promise. Manufacturers can use different sugar-reduction techniques to produce high-quality products to help reverse the negative health effects with high sugar consumption.

\section{ACKNOWLEDGMENTS}

Funding provided in part by the National Dairy Council (Rosemont, IL). The use of tradenames does not imply endorsement or lack of endorsement of those not mentioned.

\section{REFERENCES}

Abbasi, S., and A. Saeedabadian. 2015. Influences of lactose hydrolysis of milk and sugar reduction on some physical properties of ice cream. J. Food Sci. 52:367-374. https://doi.org/10.1007/s13197 -013-1011-1.

Acar, N., C. Selçuki, and E. Coşkun. 2017. DFT and TDDFT investigation of the Schiff base formed by tacrine and saccharin. J. Mol. Model. 23. https://doi.org/10.1007/s00894-016-3195-6.

Adamczak, M., D. Charubin, and W. Bednarski. 2009. Influence of reaction medium composition on enzymatic synthesis of galactooligosaccharides and lactulose from lactose concentrates prepared from whey permeate. Chem. Zvesti 63:111-116. https://doi.org/10 $.2478 / \mathrm{s} 11696-009-0010-1$. 
Adhikari, K., L. M. Dooley, E. Chambers IV, and N. Bhumiratana. 2010. Sensory characteristics of commercial lactose-free milks manufactured in the United States. Lebensm. Wiss. Technol. 43:113118. https://doi.org/10.1016/j.lwt.2009.06.017.

Allen, A. L., J. E. McGeary, and J. E. Hayes. 2013. Rebaudioside A and rebaudioside D bitterness do not covary with acesulfame$\mathrm{K}$ bitterness or polymorphisms in TAS2R9 and TAS2R31. Chemosens. Percept. 6:109-117. https://doi.org/10.1007/s12078-013 $-9149-9$.

Allgeyer, L. C., M. J. Miller, and S. Y. Lee. 2010. Drivers of liking for yogurt drinks with prebiotics and probiotics. J. Food Sci. 75. https://doi.org/10.1111/j.1750-3841.2010.01579.x.

Alm, L. 1982. Effect of fermentation on lactose, glucose, and galactose content in milk and suitability of fermented milk products for lactose intolerant individuals. J. Dairy Sci. 65:346-352. https://doi .org/10.3168/jds.S0022-0302(82)82198-X.

American Heart Association. 2017. USDA smart snacks in school beverage guidelines. Accessed August 2017. https://healthymeals.fns .usda.gov/hsmrs/SmartSnacks/BeverageGuidelines.pdf.

American Society for Clinical Nutrition. 1988. Chapter 3: Lactose content of milk and milk products. Am. J. Clin. Nutr. 48:1099-1104. https://doi.org/ajcn.nutrition.org/content/48/4/1099.extract.

Anstine, J. 2007. Organic and all natural: Do consumers know the difference? J. Appl. Econ. Policy 35:15-27. https://doi.org/10.1007/ s10603-011-9186-1.

Antenucci, R. G., and J. E. Hayes. 2014. Non-nutritive sweeteners are not super-normal stimuli. Int. J. Obes. 39:1-6. https://doi.org/10 .1038/ijo.2014.109.

Anton, S. D., C. K. Martin, H. Han, S. Coulon, W. T. Cefalu, P. Geiselman, and D. A. Williamson. 2010. Effects of stevia, aspartame, and sucrose on food intake, satiety, and postprandial glucose and insulin levels. Appetite 55:37-43. https://doi.org/10.1016/j .appet.2010.03.009

Arabie, P., and H. R. Moskowitz. 1971. The effects of viscosity upon perceived sweetness. Percept. Psychophys. 9:410-412. https://doi .org/10.3758/BF03210240.

Arbuckle, W. S. 1972. Ice Cream. 2nd ed. The AVI Publishing Company Inc., Westport, Connecticut.

Azevedo, B. M., F. L. Schmidt, and H. M. A. Bolini. 2015. High-intensity sweeteners in espresso coffee: Ideal and equivalent sweetness and time-intensity analysis. Int. J. Food Sci. Technol. 50:13741381. https://doi.org/10.1111/ijfs.12774.

Baadkar, S. V., M. S. Mukherjee, and S. S. Lele. 2014. Study on influence of age, gender and genetic variants on lactose intolerance and its impact on milk intake in adult Asian Indians. Ann. Hum. Biol. 41:548-553. https://doi.org/10.3109/03014460.2014.902992.

Bachmanov, A. A., and G. K. Beauchamp. 2007. Taste receptor genes. Annu. Rev. Nutr. 27:389-414. https://doi.org/10.1146/annurev .nutr.26.061505.111329.

Baines, Z. V., and E. R. Morris. 1987. Flavour/taste perception in thickened systems: the effect of guar gum above and below c*. Food Hydrocoll. 1:197-205. https://doi.org/10.1016/S0268 $-005 \mathrm{X}(87) 80003-6$

Baran, E. J., and V. T. Yilmaz. 2006. Metal complexes of saccharin. Coord. Chem. Rev. 250:1980-1999. https://doi.org/10.1016/j.ccr .2005.11.021.

Bayarri, S., I. Carbonell, E. X. Barrios, and E. Costell. 2011. Impact of sensory differences on consumer acceptability of yoghurt and yoghurt-like products. Int. Dairy J. 21:111-118. https://doi.org/ 10.1016/j.idairyj.2010.09.002.

Bayarri, S., I. Rivas, L. Izquierdo, and E. Costell. 2007. Influence of texture on the temporal perception of sweetness of gelled systems. Food Res. Int. 40:900-908. https://doi.org/10.1016/j.foodres.2007 .03 .003 .

Bayarri, S., A. J. Taylor, and J. Hort. 2006. The role of fat in flavor perception: Effect of partition and viscosity in model emulsions. J. Agric. Food Chem. 54:8862-8868. https://doi.org/10.1021/ jf061537k.

Bearth, A., M. E. Cousin, and M. Siegrist. 2014. The consumer's perception of artificial food additives: Influences on acceptance, risk and benefit perceptions. Food Qual. Prefer. 38:14-23. https://doi .org/10.1016/j.foodqual.2014.05.008.

Behrens, M., W. Meyerhof, C. Hellfritsch, and T. Hofmann. 2011. Sweet and umami taste: Natural products, their chemosensory targets, and beyond. Angew. Chem. Int. Ed. Engl. 50:2220-2242. https://doi.org/10.1002/anie.201002094.

Bell, L. N., and T. P. Labuza. 1991. Aspartame degradation kinetics as affected by $\mathrm{pH}$ in intermediate and low moisture food systems. J. Food Sci. 56:17-20. https://doi.org/10.1111/j.1365-2621.1991 .tb07964.x.

Bhatnagar, S., and R. Aggarwal. 2007. Lactose intolerance. BMJ 334:1331-1332. https://doi.org/10.1136/bmj.39252.524375.80.

Biguzzi, C., P. Schlich, and C. Lange. 2014. The impact of sugar and fat reduction on perception and liking of biscuits. Food Qual. Prefer. 35:41-47. https://doi.org/10.1016/j.foodqual.2014.02.001.

Birch, G. G. 1996. Towards an improved understanding of sweetener synergy. Trends Food Sci. Technol. 7:403-407. https://doi.org/10 .1016/S0924-2244(96)10041-8.

Boring, E. G. 1946. Sensation and Perception in the History of Experimental Psychology. 1st ed. Appleton Century Crofts, New York, NY

Boyer, R. 2002. Lactose intolerance: Milk sugar. Interactive Concepts in Biochemistry. 2nd ed. Accessed June 2017. http://www.wiley .com/legacy/college/boyer/0470003790/cutting_edge/lactose intolerance/lactose_intolerance.htm.

Byrd-Bredbenner, C., J. McKinley, J. Martin-Biggers, and E. Gager. 2016. Encouraging reductions in sugar-sweetened beverage consumption: HomeStyles Best Drinks for Families guide. J. Nutr. Educ. Behav. 48:S11-S12. https://doi.org/10.1016/j.jneb.2016.04 .035 .

Cadena, R. S., and H. M. A. Bolini. 2011. Time-intensity analysis and acceptance test for traditional and light vanilla ice cream. Food Res. Int. 44:677-683. https://doi.org/10.1016/j.foodres.2010 .12 .012 .

Cadena, R. S., A. G. Cruz, J. A. F. Faria, and H. M. A. Bolini. 2012. Reduced fat and sugar vanilla ice creams: sensory profiling and external preference mapping. J. Dairy Sci. 95:4842-4850. https:// doi.org/10.3168/jds.2012-5526.

Cardoso, J. M. P., and H. M. A. Bolini. 2008. Descriptive profile of peach nectar sweetened with sucrose and different sweeteners. J. Sens. Stud. 23:804-816. https://doi.org/10.1111/j.1745-459X.2008 .00187.x.

Cernivec, S. 2014. A sweet shift of share, pages 50-53 in Beverage Industry. http://digital.bnpmedia.com/publication/index.php?i= $212015 \& m=0 \& l=\& p=50 \& p r e=\#$.

Chan, K., G. Prendergast, A. Grønhøj, and T. Bech-Larsen. 2011. Danish and Chinese adolescents' perceptions of healthy eating and attitudes toward regulatory measures. Young Consumers 12:216228. https://doi.org/10.1108/17473611111163278.

Chattopadhyay, S., U. Raychaudhuri, and R. Chakraborty. 2014. Artificial sweeteners-A review. J. Food Sci. Technol. 51:611-621. https://doi.org/10.1007/s13197-011-0571-1.

Chen, M. F. 2011. The joint moderating effect of health consciousness and healthy lifestyle on consumers' willingness to use functional foods in Taiwan. Appetite 57:253-262. https://doi.org/10.1016/j appet.2011.05.305.

Childs, J. L., and M. Drake. 2009. Consumer perception of fat reduction in cheese. J. Sens. Stud. 24:902-921. https://doi.org/10.1111/ j.1745-459X.2009.00243.x.

Cho, S. 2014. Determination of the generally recognized as safe (GRAS) status of Luo Han Guo extracts as a food ingredient. FDA. Accessed August 2017. https://www.fda.gov/downloads/ Food/IngredientsPackagingLabeling/GRAS/NoticeInventory/ ucm505153.pdf.

Chollet, M., D. Gille, A. Schmid, B. Walther, and P. Piccinali. 2013. Acceptance of sugar reduction in flavored yogurt. J. Dairy Sci. 96:5501-5511. https://doi.org/10.3168/jds.2013-6610.

Collings, V. B. 1974. Human taste response as a function of locus of stimulation on the tongue and soft palate. Percept. Psychophys. 16:169-174. https://doi.org/10.3758/BF03203270. 
Cook, G. C., and A. Dahlqvist. 1968. Jejunal hetero-beta-galactosidase activities in Ugandans with lactase deficiency. Gastroenterology $55: 328-332$.

Damodaran, S., L. Kirk, and O. Fennema. 2008. Fennema's Food Chemistry. 4th ed. CRC/Taylor \& Francis Group, Boca Raton, FL

Davila-Vazquez, G., F. Alatriste-Mondragón, A. de León-Rodríguez, and E. Razo-Flores. 2008. Fermentative hydrogen production in batch experiments using lactose, cheese whey and glucose: Influence of initial substrate concentration and $\mathrm{pH}$. Int. J. Hydrogen Energy 33:4989-4997. https://doi.org/10.1016/j.ijhydene.2008.06 .065 .

Davis, E. A. 1995. Functionality of sugars: Physicochemical interactions in foods. Am. J. Clin. Nutr. 62:170S-177S.

Desai, N. T., L. Shepard, and M. A. Drake. 2013. Sensory properties and drivers of liking for Greek yogurts. J. Dairy Sci. 96:7454-7466. https://doi.org/10.3168/jds.2013-6973

Di Monaco, R., N. A. Miele, S. Volpe, D. Picone, and S. Cavella. 2014. Temporal sweetness profile of MNEI and comparison with commercial sweeteners. J. Sens. Stud. 29:385-394. https://doi.org/10 $.1111 /$ joss. 12119 .

Drake, S. L., K. Lopetcharat, and M. A. Drake. 2011. Salty taste in dairy foods: Can we reduce the salt? J. Dairy Sci. 94:636-645. https://doi.org/10.3168/jds.2010-3509.

DuBois, G. E., and J. F. Lee. 1983. A simple technique for the evaluation of temporal taste properties. Chem. Senses 7:237-248.

DuBois, G. E., and I. Prakash. 2012. Non-caloric sweeteners, sweetness modulators, and sweetener enhancers. Annu. Rev. Food Sci Technol. 3:353-380. https://doi.org/10.1146/annurev-food-022811 -101236 .

Edwards, C. H., M. Rossi, C. P. Corpe, P. J. Butterworth, and P. R. Ellis. 2016. The role of sugars and sweeteners in food, diet and health: Alternatives for the future. Trends Food Sci. Technol. 56:158-166. https://doi.org/10.1016/j.tifs.2016.07.008.

El-Neshawy, A. A., A. A. Abdel Baky, A. M. Rabie, and S. A. Metwally. 1988. Organoleptic and physical properties of ice cream made from hydrolysed lactose reconstituted milk. Food Chem. 27:83-93. https://doi.org/10.1016/0308-8146(88)90080-5.

Ellison, F. M. 2014. High-Intensity Sweeteners : An Overview; PowerPoint slides 27-56. Accessed August 2017. http://jifsan.umd.edu/ images/wordpress/2014/11/2014NutritionWebinarDay2_Ellison .pdf.

Engel, W. G. 1973. The use of lactase to sweeten yogurt without increasing calories. Cult. Dairy Prod. J. 8:6.

Erkaya, T., E. Dağdemir, and M. Sengül. 2012. Influence of Cape gooseberry (Physalis peruviana L.) addition on the chemical and sensory characteristics and mineral concentrations of ice cream. Food Res. Int. 45:331-335. https://doi.org/10.1016/j.foodres.2011 .09 .013 .

FARE. 2013. What Is a Food Allergy? Food Allergy Research \& Education. Accessed September 2017. https://www.foodallergy.org/ life-with-food-allergies/food-allergy-101/what-is-a-food-allergy.

FDA (Food and Drug Administration). 1981. Federal Register (July 24, 1981): Aspartame. Accessed April 2017. https:// www.fda.gov/downloads/Food/IngredientsPackagingLabeling/ FoodAdditivesIngredients/UCM404380.pdf.

FDA (Food and Drug Administration). 2004. Overview of food ingredients, additives and colors. Accessed August 2017. https://www.fda .gov/food/ingredientspackaginglabeling/foodadditivesingredients/ ucm094211.htm.

FDA (Food and Drug Administration). 2014. Generally recognized as safe (GRAS). Accessed June 2017. https://www.fda.gov/food/ ingredientspackaginglabeling/gras/.

FDA (Food and Drug Administration). 2015a. Additional information about high-intensity sweeteners permitted for use in food in the United States. Accessed May 2017. https://www.fda.gov/food/ ingredientspackaginglabeling/foodadditivesingredients/ucm397725 .htm.

FDA (Food and Drug Administration). 2015b. Problems digesting dairy products? Accessed January 2017. https://www.fda.gov/ forconsumers/consumerupdates/ucm094550.htm.
FDA (Food and Drug Administration). 2015c. GRAS Notice (GRN) No. 572. Accessed January 2017. https://www.fda.gov/ forconsumers/consumerupdates/ucm094550.htm.

FDA (Food and Drug Administration). 2016a. Changes to the $\mathrm{Nu}-$ trition Facts label. Accessed January 2017. https://www.fda.gov/ forconsumers/consumerupdates/ucm094550.htm.

FDA (Food and Drug Administration). 2016b. "Natural" on food labeling. Accessed November 2017. https://www.fda.gov/Food/ GuidanceRegulation/GuidanceDocumentsRegulatoryInformation/ LabelingNutrition/ucm456090.htm

FDA (Food and Drug Administration). 1983. Food Code Department of Health and Human Services. Public Health Service Food and Drug Administration. Accessed May 2017. https://www.fda .gov/downloads/food/guidanceregulation/retailfoodprotection/ foodcode/ucm374510.pdf.

Fox, P. F., and P. L. H. McSweeney. 2003. Advanced Dairy Chemistry. Kluwer Academic/Plenum, New York.

Frankowski, K. M., R. E. Miracle, and M. A. Drake. 2014. The role of sodium in the salty taste of permeate. J. Dairy Sci. 97:5356-5370. https://doi.org/10.3168/jds.2014-8057.

Frøst, M. B., H. Heymann, W. L. P. Bredie, G. B. Dijksterhuis, and M. Martens. 2005. Sensory measurement of dynamic flavour intensity in ice cream with different fat levels and flavourings. Food Qual. Prefer. 16:305-314. https://doi.org/10.1016/j.foodqual.2004 .05.009.

Fujimaru, T., J. H. Park, and J. Lim. 2012. Sensory characteristics and relative sweetness of tagatose and other sweeteners. J. Food Sci. 77. https://doi.org/10.1111/j.1750-3841.2012.02844.x.

Ganchrow, J. R.. J. E. Steiner, and M. Daher. 1983. Neonatal facia expressions in response to different qualities and intensities of gustatory stimuli. Infant Behav. Dev. 6:473-484. https://doi.org/10 .1016/S0163-6383(83)90301-6.

Gelardi, R. C. 1987. The multiple sweetener approach and new sweeteners on the horizon. Food Technol. http://agris.fao.org/agris -search/search.do? recordID=US883265188.

Gerdes, S. 2012. Consumers have a thirst for protein beverages. Dairy Foods 113:22.

Goff, H. D. 2015. Ice Cream and Frozen Desserts. Wiley-VCH Verlag GmbH \& Co. KGaA, Weinheim, Germany. https://doi.org/10 .1002/14356007.a13_563.pub2.

Goldfein, K. R., and J. L. Slavin. 2015. Why sugar is added to food: Food science 101. Compr. Rev. Food Sci. Food Saf. 14:644-656. https://doi.org/10.1111/1541-4337.12151.

Grembecka, M. 2015. Sugar alcohols-Their role in the modern world of sweeteners: A review. Eur. Food Res. Technol. 241:1-14. https:/ /doi.org/10.1007/s00217-015-2437-7.

Grygorczyk, A., I. Lesschaeve, M. Corredig, and L. Duizer. 2013. Extraction of consumer texture preferences for yogurt: Comparison of the preferred attribute elicitation method to conventional profiling. Food Qual. Prefer. 27:215-222. https://doi.org/10.1016/j .foodqual.2012.02.017.

Guggisberg, D., P. Piccinali, and K. Schreier. 2011. Effects of sugar substitution with stevia, Actilight and stevia combinations or Palatinose on rheological and sensory characteristics of low-fat and whole milk set yoghurt. Int. Dairy J. 21:636-644. https://doi.org/ 10.1016/j.idairyj.2011.03.010.

Guinard, J. X., C. Zoumas-Morse, L. Mori, D. Panyam, and A. Kilara. 1996. Effect of sugar and fat on the acceptability of vanilla ice cream. J. Dairy Sci. 79:1922-1927. https://doi.org/10.3168/jds .S0022-0302(96) 76561-X

Hanger, L. Y., A. Lotz, and S. Lepeniotis. 1996. Descriptive profiles of selected high intensity sweeteners (HIS), HIS blends, and sucrose. J. Food Sci. 61:456-464. https://doi.org/10.1111/j.1365-2621.1996 .tb14216.x.

Harju, M., H. Kallioinen, and O. Tossavainen. 2012. Lactose hydrolysis and other conversions in dairy products: Technological aspects. Int. Dairy J. 22:104-109. https://doi.org/10.1016/j.idairyj.2011.09 .011 .

Harper, S. J., D. L. Barnes, F. W. Bodyfelt, and M. R. McDaniel. 1991. Sensory ratings of commercial plain yogurts by consumer 
and descriptive panels. J. Dairy Sci. 74:2927-2935. https://doi .org/10.3168/jds.S0022-0302(91)78476-2.

Harrison, T. J., and G. R. Dake. 2005. An expeditious, high-yielding construction of the food aroma compounds 6-acetyl-1,2,3,4-tetrahydropyridine and 2-acetyl-1-pyrroline. J. Org. Chem. 70:1087210874. https://doi.org/10.1021/jo051940a.

Harwood, M. L., J. R. Loquasto, R. F. Roberts, G. R. Ziegler, and J. E. Hayes. 2013. Explaining tolerance for bitterness in chocolate ice cream using solid chocolate preferences. J. Dairy Sci. 96:49384944. https://doi.org/10.3168/jds.2013-6715.

Harwood, M. L., G. R. Ziegler, and J. E. Hayes. 2012. Rejection thresholds in chocolate milk: Evidence for segmentation. Food Qual. Prefer. 26:128-133. https://doi.org/10.1016/j.foodqual.2012 .04 .009 .

Hoppert, K., S. Zahn, L. Jänecke, R. Mai, S. Hoffmann, and H. Rohm. 2013. Consumer acceptance of regular and reduced-sugar yogurt enriched with different types of dietary fiber. Int. Dairy J. 28:1-7. https://doi.org/10.1016/j.idairyj.2012.08.005.

Hoppert, K., S. Zahn, A. Puschmann, I. Ullmann, and H. Rohm. 2012. Quantification of sensory difference thresholds for fat and sweetness in dairy-based emulsions. Food Qual. Prefer. 26:52-57. https: //doi.org/10.1016/j.foodqual.2012.03.008.

IDFA (International Dairy Foods Association). 2010. Dairy Facts. 2010 Edition. Accessed January 2017. http://www.jimogden.com/ files/D.P._ Information.pdf.

IDFA (International Dairy Foods Association). 2017. Dairy Industry Applauds USDA Secretary Perdue for Supporting School Milk Options. Accessed June 2017. http://www.idfa.org/news-views/ news-releases/article/2017/05/01/dairy-industry-applauds-usda -secretary-perdue-for-supporting-school-milk-options.

Ingram, C. J. E., C. A. Mulcare, Y. Itan, M. G. Thomas, and D. M. Swallow. 2009. Lactose digestion and the evolutionary genetics of lactase persistence. Hum. Genet. 124:579-591. https://doi.org/10 .1007/s00439-008-0593-6.

Isik, U., D. Boyacioglu, E. Capanoglu, and D. Nilufer Erdil. 2011. Frozen yogurt with added inulin and isomalt. J. Dairy Sci. 94:16471656. https://doi.org/10.3168/jds.2010-3280.

Jelen, P., and O. Tossavainen. 2003. Low lactose and lactose-free milk and dairy products-Prospects, technologies and applications. Aust. J. Dairy Technol. 58:161-165.

Jeong, M., J. S. Gilmore, A. Bleakley, and A. Jordan. 2014. Local news media framing of obesity in the context of a sugar-sweetened beverage reduction media campaign. J. Nutr. Educ. Behav. 46:583-588. https://doi.org/10.1016/j.jneb.2014.04.294.

Jervis, S. M., J. M. Ennis, and M. A. Drake. 2012a. A comparison of adaptive choice-based conjoint and choice-based conjoint to determine key choice attributes of sour cream with limited sample size. J. Sens. Stud. 27:451-462. https://doi.org/10.1111/joss.12009.

Jervis, S. M., K. Lopetcharat, and M. A. Drake. 2012b. Application of ethnography and conjoint analysis to determine key consumer attributes for latte-style coffee beverages. J. Sens. Stud. 27:48-58. https://doi.org/10.1111/j.1745-459X.2011.00366.x.

Johnson, R. K., C. Frary, and M. Q. Wang. 2002. The nutritional consequences of flavored-milk consumption by school-aged children and adolescents in the United States. J. Am. Diet. Assoc. 102:853-856. https://doi.org/10.1016/S0002-8223(02)90192-6.

Kälviäinen, N., K. Roininen, and H. Tuorila. 2003. The relative importance of texture, taste and aroma on a yogurt-type snack food preference in the young and the elderly. Food Qual. Prefer. 14:177186. https://doi.org/10.1016/S0950-3293(02)00049-6.

Kapoor, R., L. E. Metzger, A. C. Biswas, and K. Muthukummarappan. 2007. Effect of natural cheese characteristics on process cheese properties. J. Dairy Sci. 90:1625-1634. https://doi.org/10 $.3168 /$ jds.2006-746.

Kappes, S. M., S. J. Schmidt, and S. Y. Lee. 2006. Mouthfeel detection threshold and instrumental viscosity of sucrose and high fructose corn syrup solutions. J. Food Sci. 71. https://doi.org/10.1111/j $.1750-3841.2006 .00174 . x$.

Karaca, O. B., M. Güven, K. Yasar, S. Kaya, and T. Kahyaoglu. 2009. The functional, rheological and sensory characteristics of ice creams with various fat replacers. Int. J. Dairy Technol. 62:93-99. https://doi.org/10.1111/j.1471-0307.2008.00456.x.

Karam, M. C., C. Gaiani, C. Hosri, J. Burgain, and J. Scher. 2013. Effect of dairy powders fortification on yogurt textural and sensorial properties: a review. J. Dairy Res. 80:400-409. https://doi.org/10 $.1017 /$ S0022029913000514.

Keusch, G. T., F. J. Troncale, L. H. Miller, V. Promadhat, and P. R. Anderson. 1969. Acquired lactose malabsorption in Thai children. Pediatrics 43:540-545.

Kim, M. K., K. Lopetcharat, and M. A. Drake. 2013. Influence of packaging information on consumer liking of chocolate milk. J. Dairy Sci. 96:4843-4856. https://doi.org/10.3168/jds.2012-6399.

Kim, N. C., and A. D. Kinghorn. 2002. Highly sweet compounds of plant origin. Arch. Pharm. Res. 25:725-746. https://doi.org/10 .1007/BF02976987.

Koeferli, C. R. S., P. Piccinali, and S. Sigrist. 1996. The influence of fat, sugar and non-fat milk solids on selected taste, flavor and texture parameters of a vanilla ice-cream. Food Qual. Prefer. 7:69-79. https://doi.org/10.1016/0950-3293(95)00038-0.

Kosikowski, F. V. 1979. Low lactose yogurts and milk beverages by ultrafiltration. J. Dairy Sci. 62:41-46. https://doi.org/10.3168/jds .S0022-0302(79)83198-7.

Kroger, M., K. Meister, and R. Kava. 2006. Low-calorie sweeteners and other sugar substitutes: A review of the safety issues. Compr. Rev. Food Sci. Food Saf. 5:35-47. https://doi.org/10.1111/j.1541 -4337.2006.tb00081.x.

Kubica, P., J. Namieśnik, and A. Wasik. 2015. Determination of eight artificial sweeteners and common Stevia rebaudiana glycosides in non-alcoholic and alcoholic beverages by reversed-phase liquid chromatography coupled with tandem mass spectrometry. Anal. Bioanal. Chem. 407:1505-1512. https://doi.org/10.1007/s00216 -014-8355-x.

Kumari, A., S. Choudhary, S. Arora, and V. Sharma. 2016. Stability of aspartame and neotame in pasteurized and in-bottle sterilized flavoured milk. Food Chem. 196:533-538. https://doi.org/10.1016/j .foodchem.2015.09.082.

Küster, I., and N. Vila. 2017. Healthy lifestyle and eating perceptions: Correlations with weight and low-fat and low-sugar food consumption in adolescence. Front. Life Sci. 10:48-62. https://doi.org/10 $.1080 / 21553769.2017 .1329170$.

Larsen, J. C. 2012. Artificial sweeteners. Nutrafoods 11:3-9. https:// doi.org/10.1007/s13749-012-0003-5.

Lawless, H. T., and H. Heymann. 2010. Sensory Evaluation of Food. 2nd ed. Springer-Verlag, New York, NY.

Leksrisompong, P. P., K. Lopetcharat, B. Guthrie, and M. A. Drake. 2012. Descriptive analysis of carbonated regular and diet lemonlime beverages. J. Sens. Stud. 27:247-263. https://doi.org/10 $.1111 /$ j.1745-459X.2012.00389.x.

Li, X. E., and M. A. Drake. 2015. Sensory perception, nutritional role, and challenges of flavored milk for children and adults. J. Food Sci. 80:R665-R670. https://doi.org/10.1111/1750-3841.12828.

Li, X. E., K. Lopetcharat, and M. A. Drake. 2014. Extrinsic attributes that influence parents' purchase of chocolate milk for their children. J. Food Sci. 79. https://doi.org/10.1111/1750-3841.12515.

Li, X. E., K. Lopetcharat, and M. A. Drake. 2015a. Parents' and children's acceptance of skim chocolate milks sweetened by monk fruit and stevia leaf extracts. J. Food Sci. 80:S1083-S1092. https://doi .org/10.1111/1750-3841.12835.

Li, X. E., K. Lopetcharat, Y. Qiu, and M. A. Drake. 2015b. Sugar reduction of skim chocolate milk and viability of alternative sweetening through lactose hydrolysis. J. Dairy Sci. 98:1455-1466. https:/ /doi.org/10.3168/jds.2014-8490.

Lindemann, B. 2001. Receptors and transduction in taste. Nature 413:219-225. https://doi.org/10.1038/35093032.

Lopez, M. C., L. M. Medina, and R. Jordano. 1998. Survival of lactic acid bacteria in commercial frozen yogurt. J. Food Sci. 63:706-708. https://doi.org/10.1111/j.1365-2621.1998.tb15818.x.

Lustig, R. H., L. Schmidt, and C. Brindis. 2012. The toxic truth about sugar. Nature 482:27-29. https://doi.org/10.1038/482027a. 
Macgregor, G. A., and K. M. Hashem. 2014. Action on sugar-lessons from UK salt reduction programme. Lancet 383:929-931. https:// doi.org/10.1016/S0140-6736(14)60200-2.

Magenis, R. B., E. S. Prudêncio, R. D. M. C. Amboni, N. G. Cerqueira, R. V. B. Oliveira, V. Soldi, and H. D. Benedet. 2006. Compositional and physical properties of yogurts manufactured from milk and whey cheese concentrated by ultrafiltration. Int. J. Food Sci. Technol. 41:560-568. https://doi.org/10.1111/j.1365 $-2621.2005 .01100 . x$

Mahar, A., and L. M. Duizer. 2007. The effect of frequency of consumption of artificial sweeteners on sweetness liking by women. J. Food Sci. 72:S714-718. https://doi.org/10.1111/j.1750-3841.2007 .00573.x.

Mahoney, R. R. 1998. Galactosyl-oligosaccharide formation during lactose hydrolysis: A review. Food Chem. 63:147-154. https://dol .org/10.1016/S0308-8146(98)00020-X.

Majeed, M., A. Sameen, M. Usman, M. A. Shariati, and V. K. Hristova. 2017. Impact of cheese whey protein on growth performance of broiler: An approach of cheese whey utilization in poultry feed. J. Microbiol. Biotechnol. Food Sci. 6:1117-1120. https://doi.org/ 10.15414/jmbfs.2017.6.4.1117-1120.

Malone, M. E., I. A. M. Appelqvist, and I. T. Norton. 2003. Oral behaviour of food hydrocolloids and emulsions. Part 2. Taste and aroma release. Food Hydrocoll. 17:775-784. https://doi.org/10 1016/S0268-005X(03)00098-5.

Mann, J., S. Mallard, and L. Te Morenga. 2013. Dietary sugars and body weight: Systematic review and meta-analyses of randomised controlled trials and cohort studies. BMJ 345:e7492. https://doi .org/10.1136/bmj.e7492.

Margolskee, R. F. 2002. Molecular mechanisms of bitter and sweet taste transduction. J. Biol. Chem. 277:1-4. https://doi.org/10 $.1074 /$ jbc.R100054200.

Marshall, R. T., H. D. Goff, and R. W. Hartel. 2003. Ice Cream. 7th ed. Kluwer Academic/Plenum Publishers, New York, NY.

Mazza, G. 1998. Functional Foods: Biochemical \& Processing Aspects. Technomic Publishing Company Inc., Lancaster, PA.

McLean, K. G., D. J. Hanson, S. M. Jervis, and M. A. Drake. 2017. Consumer perception of retail pork bacon attributes using adaptive choice-based conjoint analysis and maximum differential scaling. J. Food Sci. 82:2659-2668. https://doi.org/10.1111/1750-3841 .13934 .

Mekonnen, T. A., M. C. Odden, P. G. Coxson, D. Guzman, J. Lightwood, Y. C. Wang, and K. Bibbins-Domingo. 2013. Health benefits of reducing sugar-sweetened beverage intake in high risk populations of California: Results from the Cardiovascular Disease (CVD) policy model. PLoS One 8:e81723. https://doi.org/10 .1371/journal.pone.0081723.

Meyers, B., and M. S. Brewer. 2008. Sweet taste in man: A review. J. Food Sci. 73:R81-90. https://doi.org/10.1111/j.1750-3841.2008 00832.x.

Mitchell, H. 2007. Sweeteners and Sugar Alternatives in Food Technology. Blackwell Publishing, Oxford, UK.

Mizukoshi, M., T. Kawada, and N. Matsui. 1979. Model studies of cake baking. I. Continuous observations of starch gelatinization and protein coagulation during baking. Cereal Chem. 56:305-309.

Morais, E. C., A. R. Morais, A. G. Cruz, and H. M. A. Bolini. 2014 Development of chocolate dairy dessert with addition of prebiotics and replacement of sucrose with different high-intensity sweeteners. J. Dairy Sci. 97:2600-2609. https://doi.org/10.3168/jds.2013 $-7603$

Moss, M. 2013. Salt Sugar Fat: How the Food Giants Hooked Us. McClelland \& Stewart, Toronto, Canada.

Muir, D. D., E. A. Hunter, S. A. R. Williams, and R. M. Brennan. 1998. Sensory profiles of commercial fruit juice drinks: Influence of sweetener type J. Sci. Food Agric. 77:559-565. https://doi.org/ $10.1002 /$ fsn3.195.

Murphy, M. M., J. S. Douglass, R. K. Johnson, and L. A. Spence. 2008. Drinking flavored or plain milk is positively associated with nutrient intake and is not associated with adverse effects on weight status in US children and adolescents. J. Am. Diet. Assoc. 108:631-639. https://doi.org/10.1016/j.jada.2008.01.004.
Narayanan, P., B. Chinnasamy, L. Jin, and S. Clark. 2014. Use of justabout-right scales and penalty analysis to determine appropriate concentrations of stevia sweeteners for vanilla yogurt. J. Dairy Sci. 97:3262-3272. https://doi.org/10.3168/jds.2013-7365.

Nie, Y., S. Vigues, J. R. Hobbs, G. L. Conn, and S. D. Munger. 2008. T1R2, T1R3, and the detection of sweet stimuli. ACS Symp. Ser. 979:65-75. https://doi.org/10.1021/bk-2008-0979.ch004.

Nijdam, J. J., and T. A. G. Langrish. 2006. The effect of surface composition on the functional properties of milk powders. J. Food Eng. 77:919-925. https://doi.org/10.1016/j.jfoodeng.2005.08.020.

Nofre, C., and J. M. Tinti. 2000. Neotame: Discovery, properties, utility. Food Chem. 69:245-257. https://doi.org/10.1016/S0308 -8146(99)00254-X.

Norwood, E. A., S. Pezennec, J. Burgain, V. Briard-Bion, P. Schuck, T. Croguennec, R. Jeantet, and C. Le Floch-Fouéré. 2017. Crucial role of remaining lactose in whey protein isolate powders during storage. J. Food Eng. 195:206-216. https://doi.org/10.1016/j .jfoodeng.2016.10.010.

Nurgel, C., and G. Pickering. 2005. Contribution of glycerol, ethanol and sugar to the perception of viscosity and density elicited by model white wines. J. Texture Stud. 36:303-323. https://doi.org/ 10.1111/j.1745-4603.2005.00018.x.

Oh, D. K. 2007. Tagatose: Properties, applications, and biotechnological processes. Appl. Microbiol. Biotechnol. 76:1-8. https://doi .org/10.1007/s00253-007-0981-1.

Oliveira, D., L. Antúnez, A. Giménez, J. C. Castura, R. Deliza, and G. Ares. 2015. Sugar reduction in probiotic chocolate-flavored milk: Impact on dynamic sensory profile and liking. Food Res. Int. 75:148-156. https://doi.org/10.1016/j.foodres.2015.05.050.

Oliveira, D., F. Reis, R. Deliza, A. Rosenthal, A. Giménez, and G. Ares. 2016. Difference thresholds for added sugar in chocolateflavoured milk: Recommendations for gradual sugar reduction. Food Res. Int. 89:448-453. https://doi.org/10.1016/j.foodres.2016 .08 .019 .

Oltman, A. E., K. Lopetcharat, E. Bastian, and M. A. Drake. 2015 Identifying key attributes for protein beverages. J. Food Sci 80:S1383-S1390. https://doi.org/10.1111/1750-3841.12877.

Ott, D. B., C. L. Edwards, and S. J. Palmer. 1991. Perceived taste intensity and duration of nutritive and non-nutritive sweeteners in water using time-intensity (T-I) evaluations. J. Food Sci. 56:535542. https://doi.org/10.1111/j.1365-2621.1991.tb05319.x.

Özer, B. H., and R. K. Robinson. 1999. The behaviour of starter cultures in concentrated yoghurt (Labneh) produced by different techniques. Lebensm. Wiss. Technol. 32:391-395. https://doi.org/ 10.1006 / fstl.1999.0566.

Page, K. A., O. Chan, J. Arora, R. Belfort-Deaguiar, J. Dzuira, B. Roehmholdt, G. W. Cline, S. Naik, R. Sinha, R. T. Constable, and R. S. Sherwin. 2013. Effects of fructose vs glucose on regional cerebral blood flow in brain regions involved with appetite and reward pathways. JAMA 309:63-70. https://doi.org/10.1001/jama .2012 .116975

Palazzo, A. B., M. A. R. Carvalho, P. Efraim, and H. M. A. Bolini 2011. The determination of isosweetness concentrations of sucralose, rebaudioside and neotame as sucrose substitutes in new diet chocolate formulations using the time-intensity analysis. J. Sens. Stud. 26:291-297. https://doi.org/10.1111/j.1745-459X.2011 .00344.x.

Pandurangan, M., J. Park, and E. Kim. 2014. Aspartame downregulates 3T3-L1 differentiation. In Vitro Cell. Dev. Biol. Anim. 50:851-857. https://doi.org/10.1007/s11626-014-9789-3.

Panesar, P. S., S. Kumari, and R. Panesar. 2010. Potential applications of immobilized $\beta$-galactosidase in food processing industries. Enzyme Res. 2010:473137. https://doi.org/10.4061/2010/473137.

Pangborn, M. 1963. Relative taste intensities of selected sugars and organic acids. J. Food Sci. 28:726-733. https://doi.org/10.1111/j .1365-2621.1963.tb01680.x.

Parasidis, E., N. Hooker, and C. T. Simons. 2015. Addressing consumer confusion surrounding "natural" food claims. Am. J. Law Med. 41:357-373. https://doi.org/10.1177/0098858815591522.

Patra, F., S. K. Tomar, and S. Arora. 2009. Technological and functional applications of low-calorie sweeteners from lactic acid bac- 
teria. J. Food Sci. 74. https://doi.org/10.1111/j.1750-3841.2008 .01005.x.

Patterson, N. J., M. J. Sadler, and J. M. Cooper. 2012. Consumer understanding of sugars claims on food and drink products. Nutr. Bull. 37:121-130. https://doi.org/10.1111/j.1467-3010.2012.01958 .x.

Pawar, R. S., A. J. Krynitsky, and J. I. Rader. 2013. Sweeteners from plants-with emphasis on Stevia rebaudiana (Bertoni) and Siraitia grosvenorii (Swingle). Anal. Bioanal. Chem. 405:4397-4407. https: //doi.org/10.1007/s00216-012-6693-0.

Pérez, S., P. Matta, C. Osella, M. De La Torre, and H. D. Sánchez. 2013. Effect of soy flour and whey protein concentrate on cookie color. LWT Food Sci. Technol. 50:120-125. https://doi.org/10 $.1016 /$ j.lwt.2012.06.015.

Pinheiro, M., and M. Oliveira. 2005. The effect of different sweeteners in low-calorie yogurts - A review. Int. J. Dairy Technol. 58:193199. https://doi.org/10.1111/j.1471-0307.2005.00228.x.

Portnoi, P. A., and A. MacDonald. 2011. The lactose content of Mini Babybel and suitability for galactosaemia. J. Hum. Nutr. Diet. 24:620-621. https://doi.org/10.1111/j.1365-277X.2011.01214.x.

Prakash, I., G. E. DuBois, J. F. Clos, K. L. Wilkens, and L. E. Fosdick. 2008. Development of rebiana, a natural, non-caloric sweetener. Food Chem. Toxicol. 46. https://doi.org/10.1016/j.fct.2008 .05 .004 .

Prindiville, E. A., R. T. Marshall, and H. Heymann. 1999. Effect of milk fat on the sensory properties of chocolate ice cream. J. Dairy Sci. 82:1425-1432. https://doi.org/10.3168/jds.S0022 -0302(99)75369-5.

Pruthi, S. 2015. Obesity Risk Factors-Mayo Clinic. Accessed Nov. 17, 2017. https://www.mayoclinic.org/diseases-conditions/obesity/ basics/risk-factors/con-20014834.

Quann, E. E., and D. Adams. 2013. Impact on milk consumption and nutrient intakes from eliminating flavored milk in elementary schools. Nutr. Today 48:127-134. https://doi.org/10.1097/NT $.0 \mathrm{~b} 013 \mathrm{e} 3182941 \mathrm{~d} 6 \mathrm{a}$.

Ramchandran, L., and T. Vasiljevic. 2012. Whey Processing. Membr. Process. Dairy Beverage Appl. 193-207. https://doi.org/10.1002/ 9781118457009.ch9.

Rasinperä, H. 2004. A genetic test which can be used to diagnose adult-type hypolactasia in children. Gut 53:1571-1576. https://doi .org/10.1136/gut.2004.040048.

Rocha, I. F., and H. M. A. Bolini. 2015. Passion fruit juice with different sweeteners: sensory profile by descriptive analysis and acceptance. Food Sci. Nutr. 3:129-139. https://doi.org/10.1002/fsn3 .195 .

Roland, A. M., L. G. Phillips, and K. J. Boor. 1999. Effects of fat content on the sensory properties, melting, color, and hardness of ice cream. J. Dairy Sci. 82:32-38. https://doi.org/10.3168/jds.S0022 -0302(99)75205-7.

Rolon, M. L., A. J. Bakke, J. N. Coupland, J. E. Hayes, and R. F. Roberts. 2017. Effect of fat content on the physical properties and consumer acceptability of vanilla ice cream. J. Dairy Sci. 100:5217-5227. https://doi.org/10.3168/jds.2016-12379.

Rona, R. J., T. Keil, C. Summers, D. Gislason, L. Zuidmeer, E. Sodergren, S. T. Sigurdardottir, T. Lindner, K. Goldhahn, J. Dahlstrom, D. McBride, and C. Madsen. 2007. The prevalence of food allergy: A meta-analysis. J. Allergy Clin. Immunol. 120:638-646. https://doi.org/10.1016/j.jaci.2007.05.026.

Routray, W., and H. N. Mishra. 2011. Scientific and technical aspects of yogurt aroma and taste: A review. Compr. Rev. Food Sci. Food Saf. 10:208-220. https://doi.org/10.1111/j.1541-4337.2011.00151 x.

Rozin, P., and P. Rozin. 2005. The meaning of "natural": Process more important than content. Psychol. Sci. 16:652-658. https://doi.org/ 10.1111/j.1467-9280.2005.01589.x.

Sahi, T., K. Launiala, and H. Laitinen. 1983. Hypolactasia in a fixed cohort of young Finnish adults. A follow-up study. Scand. J. Gastroenterol. 18:865-870.

Saint-Eve, A., I. Déléris, E. Aubin, E. Semon, G. Feron, J. M. Rabillier, D. Ibarra, E. Guichard, and I. Souchon. 2009. Influence of composition $\left(\mathrm{CO}_{2}\right.$ and sugar $)$ on aroma release and percep- tion of mint-flavored carbonated beverages. J. Agric. Food Chem. 57:5891-5898. https://doi.org/10.1021/jf900542j.

Saint-Eve, A., I. Déléris, G. Feron, D. Ibarra, E. Guichard, and I. Souchon. 2010. How trigeminal, taste and aroma perceptions are affected in mint-flavored carbonated beverages. Food Qual. Prefer. 21:1026-1033. https://doi.org/10.1016/j.foodqual.2010.05.021.

Schaafsma, G. 2008. Lactose and lactose derivatives as bioactive ingredients in human nutrition. Int. Dairy J. 18:458-465. https://doi .org/10.1016/j.idairyj.2007.11.013.

Scott, K. 2005. Taste recognition: Food for thought. Neuron 48:455464. https://doi.org/10.1016/j.neuron.2005.10.015.

Sehar, I., A. Kaul, S. Bani, H. C. Pal, and A. K. Saxena. 2008. Immune up regulatory response of a non-caloric natural sweetener, stevioside. Chem. Biol. Interact. 173:115-121. https://doi.org/10 $.1016 /$ j.cbi.2008.01.008.

Servant, G., C. Tachdjian, X. Q. Tang, S. Werner, F. Zhang, X. Li, P. Kamdar, G. Petrovic, T. Ditschun, A. Java, P. Brust, N. Brune, G. E. DuBois, M. Zoller, and D. S. Karanewsky. 2010. Positive allosteric modulators of the human sweet taste receptor enhance sweet taste. Proc. Natl. Acad. Sci. USA 107:4746-4751. https:// doi.org/10.1073/pnas.0911670107.

Shankar, P., S. Ahuja, and K. Sriram. 2013. Non-nutritive sweeteners: Review and update. Nutrition 29:1293-1299. https://doi.org/10 .1016/j.nut.2013.03.024.

Sigman-Grant, M. J., and G. Hsieh. 2005. Reported use of reducedsugar foods and beverages reflect high-quality diets. J. Food Sci. 70:S42-S46. https://doi.org/10.1111/j.1365-2621.2005.tb09063.x.

Silcock, P. 2017. The Basics: The Functional Role of Sugar in Food. Accessed June 2017. https://www.srasanz.org/sras/basics-sugar/ functionsuses-food/.

Silvestre, M. P. C., H. A. Morais, M. R. Silva, M. W. S. de Souza, and V. D. M. Silva. 2012. Preparation and analysis of hydrolysates from whey protein concentrate using the proteases from Bacillus licheniformis and Aspergillus oryzae. Int. J. Food Sci. Technol. 47:1532-1539. https://doi.org/10.1111/j.1365-2621.2012.03003.x.

Sirshendu, D., M. Sourav, and B. Suvrajit. 2013. Applications of Stevioside. 1st ed. John Wiley \& Sons, Ltd., Oxford, UK.

Skinner, M., M. Lim, A. Tarrega, R. Ford, R. Linforth, A. Thomas, and J. Hort. 2017. Investigating the oronasal contributions to metallic perception. Int. J. Food Sci. Technol. 52:1299-1306.

Skryplonek, K., D. Gomes, J. Viegas, C. Pereira, and M. Henriques. 2017. Lactose-free frozen yogurt: Production and characteristics. Acta Sci. Pol. Technol. Aliment. 16:171-179.

Smith, S. T., L. Metzger, and M. A. Drake. 2016. Evaluation of whey, milk, and delactosed permeates as salt substitutes. J. Dairy Sci. 99:8687-8698. https://doi.org/10.3168/jds.2016-10904.

Sodini, I., F. Remeuf, S. Haddad, and G. Corrieu. 2010. The relative effect of milk base, starter, and process on yogurt texture: A review. Crit. Rev. Food Sci. Nutr. 44:113-137. https://doi.org/10 $.1080 / 10408690490424793$.

Suarez, F. L., D. A. Savaiano, and M. D. Levitt. 1995. A comparison of symptoms after the consumption of milk or lactose-hydrolyzed milk by people with self-reported severe lactose intolerance. N. Engl. J. Med. 333:1-4. https://doi.org/10.1056/NEJM199507063330101.

Sun-Waterhouse, D., L. Edmonds, S. S. Wadhwa, and R. Wibisono. 2013. Producing ice cream using a substantial amount of juice from kiwifruit with green, gold or red flesh. Food Res. Int. 50:647656. https://doi.org/10.1016/j.foodres.2011.05.030.

Tadesse, K., D. Leung, and R. Yuen. 1992. The status of lactose absorption in Hong Kong Chinese children. Acta Paediatr. 81:598600. https://doi.org/10.1111/j.1651-2227.1992.tb12308.x.

Tamime, A. Y., and H. C. Deeth. 1980. Yogurt: Technology and biochemistry. J. Food Prot. 43:939-977. https://doi.org/10.4315/0362 $-028 \mathrm{X}-43.12 .939$.

Thompson, A. K., and P. J. Moughan. 2008. Innovation in the foods industry: Functional foods. Br. Food J. 110:144-155. https://doi .org/10.1108/00070700810844830.

Thompson, J. L., M. A. Drake, K. Lopetcharat, and M. D. Yates. 2004. Sensory and nutritive qualities of food preference mapping of commercial chocolate milks. J. Food Sci. 69:406-413. 
Thompson, J. L., K. Lopetcharat, and M. A. Drake. 2007. Preferences for commercial strawberry drinkable yogurts among African American, Caucasian, and Hispanic consumers in the United States. J. Dairy Sci. 90:4974-4987. https://doi.org/10.3168/jds.2007-0313.

Toniolo, C., and P. Temussi. 2016. Conformational flexibility of aspartame. Biopolymers 106:376-384. https://doi.org/10.1002/bip .22847 .

Troelsen, J. T. 2005. Adult-type hypolactasia and regulation of lactase expression. Biochim. Biophys. Acta 1723:19-32. https://doi.org/ $10.1016 /$ j.bbagen.2005.02.003

USDA. 2008. What is the definition of a processing aid? Accessed January 2017. https://askfsis.custhelp.com/app/answers/detail/ a_id $/ 946 / \sim$ what-is-the-definition-of-a-processing-aid $\% 3 \mathrm{~F}$.

USDA. 2015. Nutritive and nonnutritive sweetener resources. Accessed April 2017. https://www.nal.usda.gov/fnic/nutritive-and -nonnutritive-sweetener-resources.

USDA-HHS (Department of Health and Human Services). 2015. Dietary Guidelines for Americans. Accessed June 2017. https:/ health.gov/dietaryguidelines/2015/guidelines/appendix-3/.

Van Horn, L., R. K. Johnson, B. D. Flickinger, D. K. Vafiadis, and S. Yin-Piazza. 2010. Translation and implementation of added sugars consumption recommendations a conference report from the American Heart Association Added Sugars Conference 2010. Circulation 122:2470-2490. https://doi.org/10.1161/CIR.0b013e3181ffdcb0.

Varnam, A. H., and J. P. Sutherland. 2001. Milk and Milk Products: Technology, Chemistry and Microbiology. Aspen Publishers, Gaithersburg, MD.

Varzakas, T. 2012. Sweeteners: Nutritional Aspects, Applications, and Production Technology. CRC Press, Boca Raton, FL.

Voorpostel, C. R., M. B. de L. Dutra, and H. M. A. Bolini. 2014. Sensory profile and drivers of liking for grape nectar among smoker and nonsmoker consumers. Food Sci. Technol. (Campinas) 34:164173. https://doi.org/10.1590/S0101-20612014000100024.

Waldrop, M. E., and C. F. Ross. 2014. Sweetener blend optimization by using mixture design methodology and the electronic tongue. J. Food Sci. 79:S1782-S1794. https://doi.org/10.1111/1750-3841 .12575 .

Walters, A., and M. Long. 2012. The effect of food label cues on perceptions of quality and purchase intentions among high-involvement consumers with varying levels of nutrition knowledge. J. Nutr. Educ. Behav. 44:350-354. https://doi.org/10.1016/j.jneb 2011.08.008.

Wang, Y. C., P. Coxson, Y. M. Shen, L. Goldman, and K. Bibbins-Domingo. 2012. A penny-per-ounce tax on sugar-sweetened beverages would cut health and cost burdens of diabetes. Health Aff. (Millwood) 31:199-207. https://doi.org/10.1377/hlthaff.2011.0410.

Wardy, W., P. Chonpracha, N. Chokumnoyporn, S. Sriwattana, W. Prinyawiwatkul, and W. Jirangrat. 2017. Influence of package visual cues of sweeteners on the sensory-emotional profiles of their products. J. Food Sci. 82:500-508. https://doi.org/10.1111/1750 -3841.13610 .

Whalen, C. A., T. M. Gilmore, K. R. Spurgeon, and J. G. Parsons. 1988. Yogurt manufactured from whey-caseinate blends and hy- drolyzed lactose. J. Dairy Sci. 71:299-305. https://doi.org/10 .3168/jds.S0022-0302(88)79558-2.

WHO (World Health Organization). 2003. Diet, nutrition, and the prevention of chronic diseases: Report of a Joint WHO/FAO Expert Consultation. WHO, Geneva, Switzerland. Accessed June 2018. http://www.who.int/dietphysicalactivity/publications/trs916/en/.

WHO (World Health Organization). 2017. WHO urges global action to curtail consumption and health impacts of sugary drinks. WHO, Geneva, Switzerland. Accessed June 2017. www.who.int mediacentre/news/releases/2016/curtail-sugary-drinks/en/.

Wilson, C. E., and W. E. Brown. 1997. Influence of Food Matrix Structure and Oral Breakdown During Mastication on Tempora Perception of Flavor. J. Sens. Stud. 12:69-86. https://doi.org/10 .1111/j.1745-459X.1997.tb00054.x.

Wolf, I. V., C. I. Vénica, and M. C. Perotti. 2015. Effect of reduction of lactose in yogurts by addition of $\beta$-galactosidase enzyme on volatile compound profile and quality parameters. Int. J. Food Sci. Technol. 50:1076-1082. https://doi.org/10.1111/ijfs.12745.

Woods, R. K., M. Abramson, M. Bailey, and E. H. Walters. 2001. International prevalences of reported food allergies and intolerances. Comparisons arising from the European Community Respiratory Health Survey (ECRHS) 1991-1994. Eur. J. Clin. Nutr. 55:298304. https://doi.org/10.1038/sj.ejcn.1601159.

Yebra-Biurrun, M. C. 2005. Sweeteners. Pages 562-572 in Encyclopedia of Analytical Science. Elsevier/Academic Press, San Diego, $\mathrm{CA}$

Yeon, J. Y., and S. K. Lee. 2016. Perception of sugar reduction, nutrition education, and frequency of snacking in children by the self-perceived sweet dietary habits of mothers in Busan. Nutr. Res. Pract. 10:546-554. https://doi.org/10.4162/nrp.2016.10.5.546.

Yon, B. A., R. K. Johnson, and T. R. Stickle. 2012. School children's consumption of lower-calorie flavored milk: A plate waste study. J. Acad. Nutr. Diet. 112:132-136. https://doi.org/10.1016/j.jada 2011.09.011.

Yoo, H. J., L. Machín, A. Arrúa, L. Antúnez, L. Vidal, A. Giménez, M. R. Curutchet, and G. Ares. 2017. Children and adolescents' attitudes towards sugar reduction in dairy products. Food Res. Int. 94:108-114. https://doi.org/10.1016/j.foodres.2017.02.005.

Zadow, J. G. 1986. Lactose hydrolysed dairy products. Food Technol. Aust. 38:460-463., 471.

Zahn, S., K. Hoppert, F. Ullrich, and H. Rohm. 2013. Dairy-based emulsions: Viscosity Affects fat difference thresholds and sweetness perception. Foods 2:521-533. https://doi.org/10.3390/ foods 2040521 .

Zorn, S., F. Alcaire, L. Vidal, A. Giménez, and G. Ares, 2014. Application of multiple-sip temporal dominance of sensations to the evaluation of sweeteners. Food Qual. Prefer. 36:135-143. https:// doi.org/10.1016/j.foodqual.2014.04.003.

Zygler, A., A. Wasik, A. Kot-Wasik, and J. Namieśnik. 2011. Determination of nine high-intensity sweeteners in various foods by high-performance liquid chromatography with mass spectrometric detection. Anal. Bioanal. Chem. 400:2159-2172. https://doi.org/ $10.1007 / \mathrm{s} 00216-011-4937-\mathrm{z}$ 